\title{
SIGNIFICANCE FOR INTERNATIONAL CORRELATION OF THE PERAPERTÚ FORMATION IN NORTHERN PALENCIA, CANTABRIAN MOUNTAINS. TECTONIC/STRATIGRAPHIC CONTEXT AND DESCRIPTION OF MISSISSIPPIAN AND UPPER BASHKIRIAN GONIATITES
}

\author{
Jürgen KULLMANN ${ }^{1}$, Robert H. WAGNER ${ }^{2}$ and \\ Cornelis F. WINKLER PRINS ${ }^{3}$ \\ ${ }^{1}$ Institut für Geowissenschaften der Universität Tübingen, Sigwartstraße 10, \\ D 72076 Tübingen, Germany; e-mail: Juergen.Kullmann@uni-tuebingen.de \\ ${ }^{2}$ Corresponding author: Centro Paleobotánico, Jardín Botánico de Córdoba, \\ Avda. de Linneo, s/n, E 14004 Córdoba (Spain); e-mail: cr1wagro@uco.es \\ ${ }^{3}$ Nationaal Natuurhistorisch Museum, Postbus 9517, NL 2300 RA Leiden, The \\ Netherlands; e-mail: winkler@nnm.nl
}

Kullmann, J., Wagner R. H. \& Winkler Prins, C.F. 2007. Significance for international correlation of the Perapertú Formation in northern Palencia, Cantabrian Mountains. Tectonic/stratigraphic context and description of Mississippian and Upper Bashkirian goniatites. [El significado de la Formación Perapertú para la correlación internacional, norte de Palencia, Cordillera Cantábrica. Contexto tectónico/estratigráfico y descripción de goniatítidos misisípicos y del Bashkiriense Superior.] Revista Española de Paleontología, 22 (2), 127-145. ISSN 0213-6937.

\begin{abstract}
Small ammonoid assemblages are recorded from the Perapertú Formation in northern Palencia. This is a mudstone unit with local platform limestones characterised by carbonate debris flows on the limestone margins. This unit, of Late Bashkirian to Early Moscovian age, participates in a series of southwards verging thrust slices North of a major fault zone which originated as the head (leading edge) of a large thrust sheet with an internal deformation consisting of thrust slices and at least one nappe structure. Opposed vergencies at the head of this major thrust sheet (Carrionas Thrust Front) and the Ruesga Fault which locally modifies its trace, mark the position where the northern branch of the Cantabric-Asturian arcuate fold belt has overridden the southern branch in early Westphalian (Langsettian) times. Two different palaeogeographic areas are found here in juxtaposition, i.e. the Asturian-Leonese Domain to the South and the Palentian Domain to the North. The contrasting stratigraphic developments are summarised in figure 2. Upper Bashkirian and Lower Moscovian formations elsewhere in the Cantabric-Asturian orogen are discussed, and the sporadic records of ammonoids in the lower part of the Pennsylvanian in various parts of the Cantabrian Mountains are commented on. The chronostratigraphic significance of the Perapertú Formation is discussed in the context of marine-terrestrial correlations for the Late Bashkirian-Early Moscovian time interval. It is concluded that the evidence from NW Spain suggests a position of the base of the Moscovian at the level of basal Westphalian or even within the highest Namurian. A brief analysis of the literature shows this position to be different to some of the correlations admitted in recent publications.

A newly discovered goniatite fauna from the lower part of the Perapertú Formation contains Branneroceras sp. indicating Late Bashkirian to earliest Moscovian, and Deleshumardites cantabricus Kullmann gen. et sp. nov. This fauna is figured and described in conjunction with the new subfamily Dombaritinae Kullmann (family Delepinoceratidae). The new genus Deleshumardites is erected with "Proshumardites" delepinei Schindewolf, 1939 as its type species. Ammonoid descriptions and illustrations include that of Deleshumardites cantabricus sp. nov. from strata of an earlier, Serpukhovian age in northern León.
\end{abstract}

Keywords: Ammonoids, Carboniferous, Bashkirian, Moscovian, Westphalian, Palentian Domain, Cantabrian Mountains, Tectonics. 


\section{RESUMEN}

Se dan a conocer dos faunas de ammonoideos de la Formación Perapertú (norte de Palencia). Se trata de una unidad lutítica que incorpora plataformas carbonatadas de cuyos márgenes procedían debris flow calcáreos. Esta formación, de edad Bashkiriense Superior a Moscoviense Inferior, se encuentra en una serie de escamas tectónicas de vergencia Sur que forman parte de un cabalgamiento de grandes dimensiones donde la rama Norte del orógeno Cántabro-Astúrico cabalga a la rama Sur. Las vergencias opuestas en este frente (Cabalgamiento de Carrionas) y la Falla de Ruesga que lo modifica, indican el lugar donde dos áreas paleogeográficas diferentes se ponen en contacto sobre el mapa. Son los dominios Astur-Leonés y Palentino, al Sur y al Norte, respectivamente (Fig. 2). Se indican las formaciones equivalentes a la Fm. Perapertú en otras partes del orógeno, y se mencionan los registros esporádicos de ammonoideos del Pensilvánico inferior en la Cordillera Cantábrica. Por otro lado, se comenta el significado cronoestratigráfico de la Formación Perapertú en relación con las correlaciones entre las escalas marinas y continentales para el intervalo Bashkiriense Superior/Moscoviense Inferior. Se llega a la conclusión de que los datos obtenidos en el NO de España sugieren que la base del Moscoviense coincide aproximadamente con la del Westfaliense, o se sitúa aún más abajo, en el Namuriense superior. Esta conclusión discrepa con algunas correlaciones admitidas en publicaciones recientes, que se mencionan escuetamente.

Por último, se describen y figuran varios ammonoideos del Pensilvánico inferior en la Cordillera Cantábrica. La nueva fauna de goniatítidos en la parte inferior de la Formación Perapertú incluye Branneroceras sp. del Bashkiriense Superior al Moscoviense más bajo (Langsettiense), así como Deleshumardites cantabricus Kullmann gen. et sp. nov. Se describe ésta última de una localidad del Serpujoviense Superior en León, y se introduce una nueva subfamilia, Dombaritinae Kullmann, de la familia Delepinoceratidae, así como el nuevo género Deleshumardites (especie tipo “Proshumardites” delepinei Schindewolf, 1939).

\section{Palabras clave: Ammonoideos, Carbonífero, Bashkiriense, Moscoviense, Westfaliense, Dominio Palentino, Cordillera Cantábrica, Tectónica.}

\section{INTRODUCTION}

The present paper aims primarily at the documentation of a goniatite fauna of stratigraphic significance, which has been collected from a low position in the Perapertú Formation, a stratigraphic unit belonging to the Palentian Domain in the southeastern part of the Palaeozoic Cantabrian Mountains. Limestones in the higher part of this formation yielded Lower Moscovian foraminiferal faunas (Rumyantseva in Wagner \& Bowman, 1983) as well as more limited conodont assemblages (op. cit.). Calcareous mudstones associated with these limestones produced a goniatite fauna of Atokan affinities (Wagner-Gentis, 1985). The newly discovered goniatite fauna is here described by the first author (JK), who has also undertaken a reappraisal of the fauna described earlier. The opportunity has been taken also to describe a new goniatite species from a locality of different (earlier) age elsewhere in the Cantabrian Mountains, and to introduce a new genus which includes this species as well as certain elements of the Perapertú fauna.

The new find of a goniatite fauna low in the Perapertú Formation was made by the third author (CFWP) in the course of a stratigraphic and tectonic reinvestigation of a structurally complex area in northern Palencia, involving strata of pre-latest Langsettian age, i.e. below the totally unconformable Curavacas Formation which initiates a fundamentally different episode in the regional geological history. This investigation, which has been carried out over a long period of time, close to a quarter century, by two of the present writers (RHW, CFWP), initially focused on the revision of Carboniferous formations on both sides of a major fault zone, identified as the Ruesga Fault (compare Wagner \& Winkler Prins, 2000). However, it became apparent that the Ruesga Fault continued the trace of a major thrust front, which is now identified as the Carrionas Thrust (Fig. 1). Large scale thrusting produced shortening which resulted in the juxtaposition of two different palaeogeographic domains (Fig. 2). The existing geological maps, at 1:50,000 scale, proved inadequate as a base for stratigraphic revision. A certain amount of remapping thus became inevitable, for which 1:10,000 scale topographic base maps were obtained. Indeed, the geological structures proved to be much more intricate than was originally anticipated, and it was found that the tectonic interpretations as published by the different authors were often poorly constrained by factual data. Inaccurate mapping was part of the problem, but the rather imprecise use of formations and lack of attention to the evidence of stratigraphic breaks, such as palaeokarst surfaces, compounded the problem.

The stratigraphic revision of Carboniferous formations carried out by the present writers, but not yet published in detail, can only be referred to briefly in the present paper, i.e. only in so far as is necessary. One new formation is named and briefly discussed but not described in detail, this being reserved for a more exhaustive paper currently in preparation. Likewise, the complex geological structure is 
explained only in so far as has been deemed necessary for the understanding of the geological history of the area.

This involves primarily the recognition of two different facies realms, known as the Asturian-Leonese and Palentian domains, with opposed vergencies and separated by a major fault zone which Wagner \& Winkler Prins (2000) identified as the Ruesga Fault, but which more recent work has shown to be separable into the frontal part of a major thrust sheet, here named the Carrionas Thrust Front, and a normal fault which interferes with the trace of the thrust and which corresponds to the original concept of the Ruesga Fault as introduced by Kanis (1956). It is noted that the structural interpretations published by Frankenfeld (1984) and Rodríguez Fernández (1994), who postulated a southern origin of the Palentian Domain, and northern vergencies for the strata involved, proved incompatible with the field data collected by the present writers. In fact, these suggest the complete opposite. A recent paper by Keller et al. (2006) also presents a regional synthesis which bears no relation to the factual information. A full discussion of the various structural hypotheses published in the geological literature of the study area will have to be postponed in view of the biostratigraphic emphasis of the present paper.

Biostratigraphic dating of the various Carboniferous formations, up to and including lower Langsettian, is discussed with particular reference to goniatite faunas. The correlation between East European (Russian/Ukranian) chronostratigraphic units and those recognised in western Europe are discussed in the light of marine faunal and terrestrial floral data obtained in northern Palencia and the adjacent area in southern Cantabria (Liébana region).

\section{GEOLOGICAL CONTEXT}

(R.H. Wagner \& C.F. Winkler Prins)

The Palaeozoic structures of northern Palencia and adjacent parts of León and Cantabria (formerly the province of Santander) are the most complex ones of an arcuate

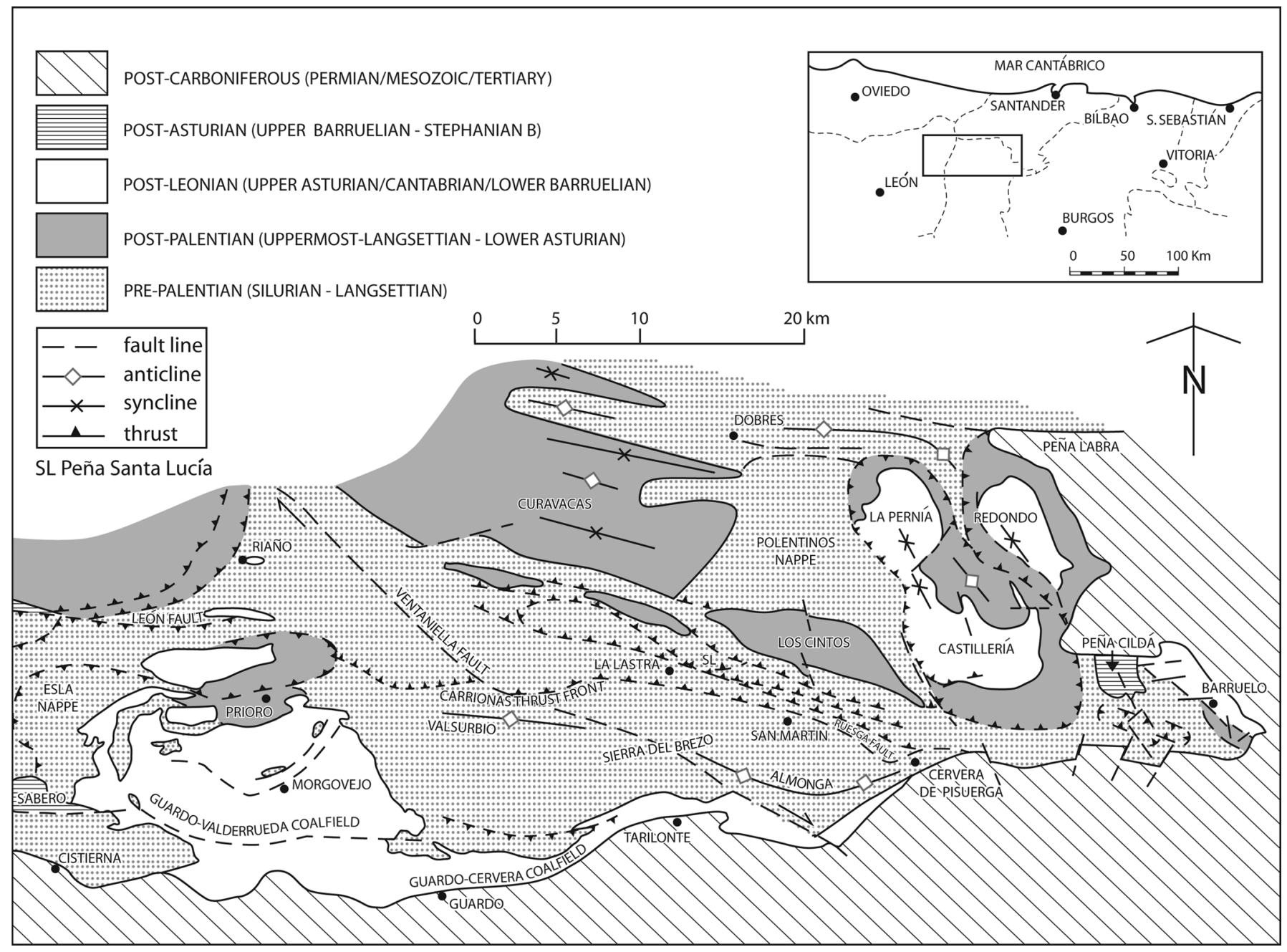

Figure 1. Outline geological map of northern Palencia and adjacent parts of NE León and southern Cantabria (southeastern part of Cantabric-Asturian arcuate fold belt). Prepared by RHW and CFWP. 
fold belt in Northwest Spain, which may be referred to as the Cantabric-Asturian Orogen. Geographically, this corresponds to most of the Cantabrian Mountains. The arcuate fold belt experienced progressive tightening in several pulses of tectonic deformation in Pennsylvanian times. Most extreme tightening took place in the eastern part of the orogen. One of these pulses, in Langsettian (early Westphalian) times, led to the strike turning around in $180^{\circ}$ in the area corresponding to northern Palencia, confronting South- and North-verging thrust units at a major geological fault zone which Wagner \& Winkler Prins (2000) identified with the Ruesga Fault, but which is presently referred to as the Carrionas Thrust Front. Major tectonic shortening took place at this fault line, with the northern branch of the arcuate fold belt overriding the southern branch (Fig. 1). It has long been recognised that two different facies and structural domains are in juxtaposition at this fault line, with the Asturian-Leonese Domain to the South and the Palentian Domain to the North. This has become apparent primarily from the rather different developments of mid- to Upper Devonian strata in these different domains (Brouwer, 1964). The sediments corresponding to the Asturian-Leonese Domain are of near-shore facies, whereas those of the Palentian domain reflect deposition more remote from shore and, consequently nearer the foreland than the hinterland. Carboniferous successions South and North of the fault zone also proved to be quite different (Wagner \& Winkler Prins, 2000, and in prep.), but this has been less immediately apparent lithologically. Previous authors (e.g. Savage in Savage \& Boschma, 1980, and Rodríguez-Fernández et al., 1985) applied formational names of generalised usage in the Carboniferous of the Cantabrian Mountains, thus blurring the differences that have now become apparent. General columns for the stratigraphic successions involved are depicted in figure 2. Stratigraphic breaks appear at different parts of the succession in the two different areas. Facies changes also operated in North-South direction. A detailed account of these facies changes, which are accompanied by thickness variations and slight differences in the stratigraphic ranges of broadly time-equivalent formations, must be left to another publication (Wagner \& Winkler Prins, in prep.) Only a brief outline of the tectonic structure may be provided here.

The major fault zone where the Asturian-Leonese and Palentian domains occur in juxtaposition, has proved to correspond basically to the frontal part of a large thrust sheet which placed the Palentian Domain on top of the Asturian-Leonese Domain (Fig. 1). This thrust sheet moved from North to South. It is here named the Carrionas Thrust
Sheet, using a regional name which reflects the major importance of this southward directed tectonic unit involving up to $4,000 \mathrm{~m}$ of strata ranging from upper Silurian to lower Pennsylvanian. Its frontal part is represented by an anticlinal structure, with overturned strata at the thrust front and small southward verging anticlines and synclines constituting the normal flank. Whereas the frontal part of the thrust sheet dips c. $30-35^{\circ} \mathrm{N}$, a number of successive thrust slices which developed within this large thrust sheet, dip generally $55^{\circ} \mathrm{N}$. These thrust slices override each other, with a progressive elimination of tectonic slices eastwards. At least one of the series of WNW-ESE striking thrust slices has developed into a fairly important nappe structure, the Polentinos Nappe (Fig. 1). Reverse thrusting at a fairly late stage of structural deformation has led to the generation of at least two small nappes involving strata of the Asturian-Leonese Domain which were moved northwards across the main thrust front (marked as Carrionas Thrust Front on the map). One of these nappes (i.e. the Revilla Nappe - Wagner, 1971), with strata which are palaeogeographically identifiable as corresponding to the northernmost part of the Asturian-Leonese Domain as found in the Sierra del Brezo (Fig. 1), is overlain in turn by a klippe of the Polentinos Nappe of the Palentian Domain; it thus being clear that one is dealing with late developments in the structural deformation of the major (Carrionas) thrust sheet. All these structures are overlain with strongly marked (highly angular) unconformity by the Curavacas Conglomerate Formation of late Langsettian and early Duckmantian ages (Wagner \& Álvarez-Vázquez, 1995), which fossilised the earlier structures. The Curavacas Formation marks the onset of a totally different phase in the geological history of northern Palencia and adjacent areas. A well developed palaeokarst is associated with the Curavacas unconformity wherever the underlying structures involve limestone formations. This palaeokarst marks the erosion surface corresponding to a period of emergence after compressive tectonic deformation.

The most complex structures associated with the Carrionas Thrust Sheet are at the head (leading edge) of this sheet. These structures are regarded as belonging to the first thrust slice within the major thrust sheet. They are cut, slightly obliquely, by the second thrust slice, which is basically subparallel, but affecting the width of outcrop of the first thrust slice, which is therefore quite variable. In the area North of San Martín de los Herreros (Fig. 3), the first thrust slice shows both the overturned flank of the anticlinal structure at the head of the Carrionas Thrust Sheet and small near-isoclinal anticlines and synclines of the normal flank (see also the section of Fig. 4). In the east-

Figure 2. Generalised columns illustrating the stratigraphic successions in Carboniferous strata of Asturian-Leonese and Palentian domains South and North of the Carrionas Thrust Front and Ruesga Fault (prepared by RHW and CFWP). The Palentian column represents the succession in the first thrust slice North of the fault. 
A (Palentian)

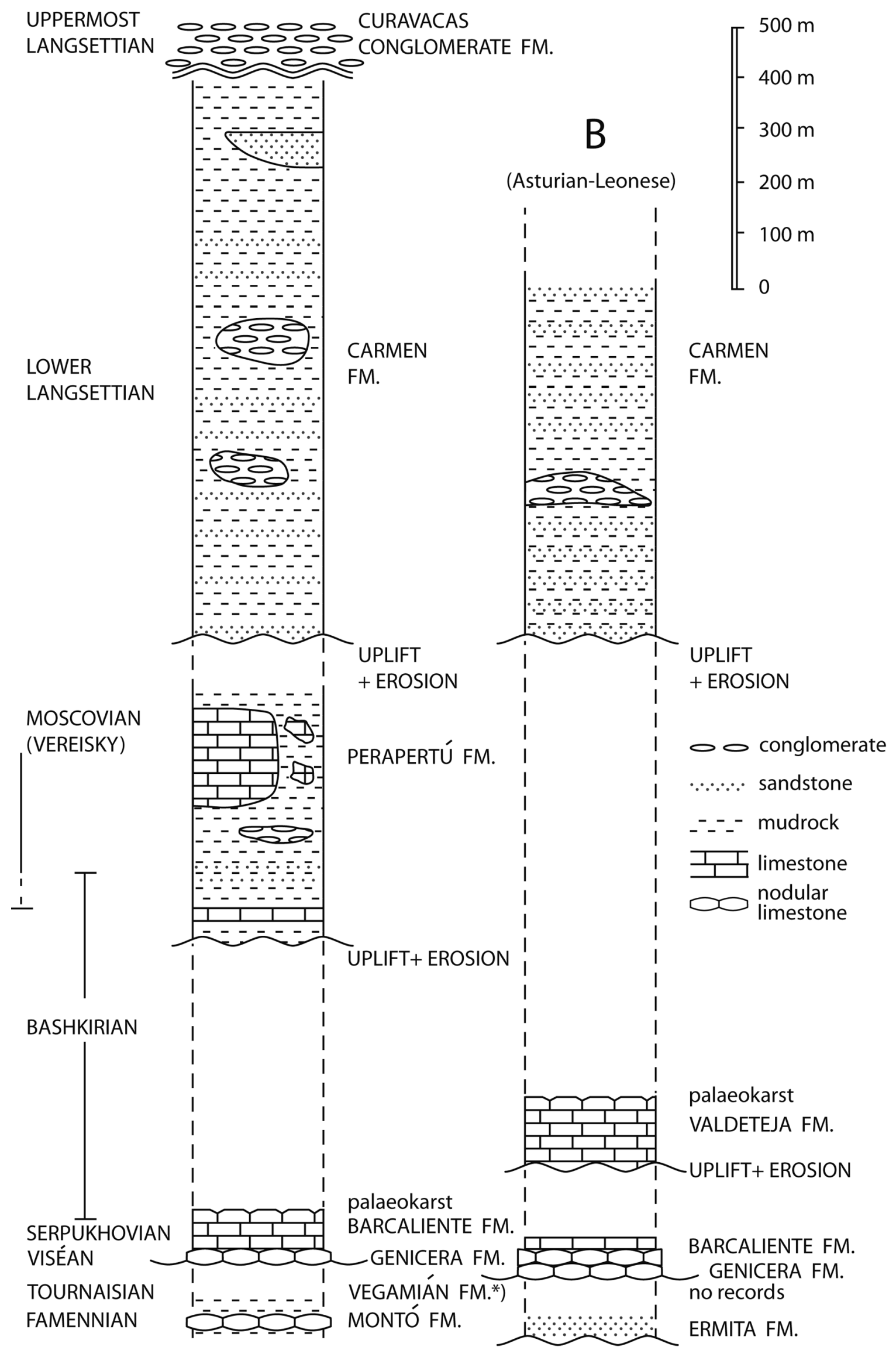


ern part of the map of figure 3, a normal fault developed which cut the overturned flank of the anticlinal structure at the head of the thrust sheet, with the progressive elimination eastwards of this overturned flank. This normal fault (Fig. 4) is here identified as the "Ruesga fracture zone" as described by Kanis (1956). On the map (Fig. 1) it continues the trace of the Carrionas Thrust Front eastwards. The fairly complex Ruesga fault zone extends further eastwards into Cervera de Pisuerga and passes underneath the Mesozoic cover, which appears to have been affected by this fracture zone; it thus seems to have been rejuvenated in Mesozoic times (Carballeira in Wagner et al., 1984, and Espina et al., 1996).

The geological structure of the area North of San Martín de los Herreros, where the recently discovered goniatite fauna has been found, is depicted in figures 3 and 4 . Originally mapped as forming part of the northward verging thrust slices found in the Sierra del Brezo (Asturian-
Leonese Domain) (Koopmans, 1964), an interpretation which has been maintained in later papers (e.g. Savage in Savage \& Boschma, 1980, and Marín, 1997), it has now proved to belong to the southward verging structures of the Palentian Domain. The map at scale 1:10,000 (Fig. 3) shows the overturned flank, with repetitions, of the anticlinal structure at the head of the Carrionas Thrust Sheet. It also shows small anticlines and synclines belonging to the normal flank, which are cut off obliquely by the steeply dipping fault underlying the second thrust slice. No detail is shown on the map for the Asturian-Leonese Domain which has been overridden by the Carrionas Thrust Sheet. Three Carboniferous formations are involved in the first thrust slice, viz. the Genicera, Barcaliente, and Perapertú formations. The latter is clearly disconformable, with a well developed palaeokarst surface on top of limestones of the Barcaliente Formation (compare Fig. 2). The newly discovered goniatite fauna, described in the present paper,

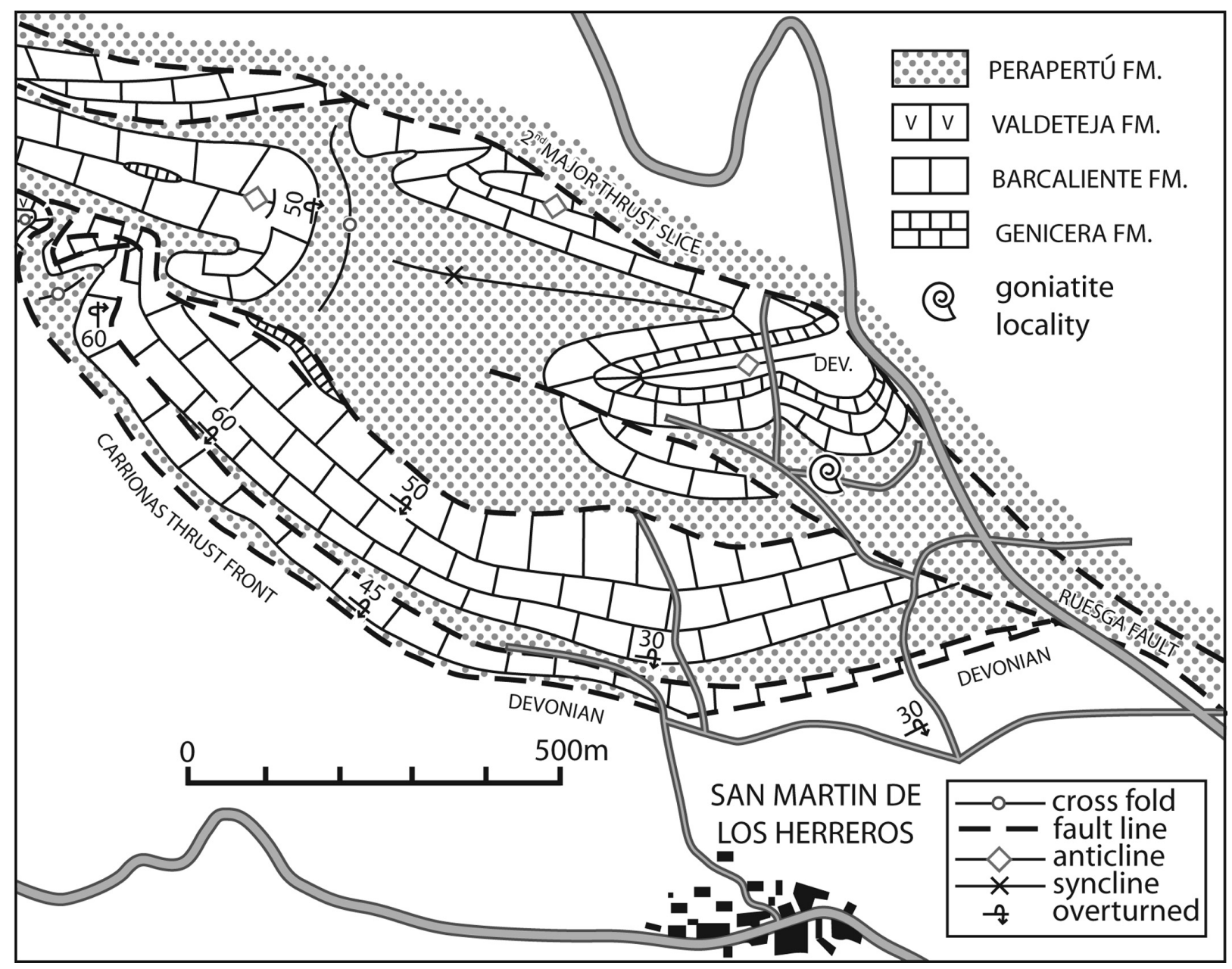

Figure 3. Geological map of the area North of San Martín de los Herreros at 1:10,000 (prepared by R.H.W. and C.F.W.P.). Represents overturned flank of anticlinal structure (with small repetitions) at the Carrionas Thrust Front, small folds in the normal flank, and the inititation of a normal fault (Ruesga Fault) which has its major development further eastwards. These structures are cut off by the second thrust slice. Note late cross-fold. Overturned symbol with arrow marking way-up. (Compare Fig. 4). 
occurs at $14 \mathrm{~m}$ above the base of the Perapertú Formation in the locality shown on the map (see also Fig. 5). A small outcrop of shales attributable to the Upper Devonian Montó (= Vidrieros) Formation occurs in the core of one of the small anticlines. It is noted that this outcrop of shales is shown on the map in Marín (1997) as a small klippe of presumed Carboniferous strata of the "Cervera" Formation. This seems an unlikely interpretation.

In the western part of the map of figure 3 , internal thrusting and a small cross fold complicate the structure of the first thrust slice of the Carrionas Thrust Sheet even further.

\section{PERAPERTÚ FORMATION}

(R.H. Wagner \& C.F. Winkler Prins)

The strata which yielded the small goniatite fauna described herein, belong to the Perapertú Formation, a stratigraphic unit of the Palentian Domain within the southward verging Carrionas Thrust Sheet (Fig. 1). This formation, defined originally by Wagner \& Wagner-Gentis (1963), has been discussed more exhaustively in Wagner et al. (1984). It is being redescribed by Wagner \& Winkler Prins (in prep.) The Perapertú Formation, which is restricted to the Palentian Domain (Fig. 2), follows in disconformable succession on a Serpukhovian to Lower Bashkirian limestone attributed to the Barcaliente Limestone Formation in the area of the first thrust slice immediately North of the
Carrionas Thrust Front. Evidence of palaeokarst is found on the limestone surface below this formation, this being the result of regional uplift in the Palentian Domain and consequent erosion (Figs 2 and 5). A fairly appreciable stratigraphic gap is involved. The Perapertú Formation has been dated in the past as Early Moscovian on foraminiferal evidence (Rumyantseva in Wagner \& Bowman, 1983). This was obtained from limestones in the higher part of the Perapertú Formation. It is overlain, again with disconformity, and palaeokarst where the appropriate lithological conditions existed, by a siliciclastic turbidite unit, the Carmen Formation. The latter is the highest stratigraphic unit occurring in the southward verging thrust slices which underlie the strongly unconformable, post-orogenic Curavacas Conglomerate Formation, of late Langsettian and early Duckmantian ages. The Carmen Formation is the same as the Cervera Formation of Brouwer \& van Ginkel (1964), a name which has been used in a rather imprecise manner by subsequent authors, and which should be avoided (compare Wagner et al., 1984). It is recalled that a mid-Bashkirian (Tashatinsky) age has been claimed for the "Cervera Formation" in the Asturian-Leonese Domain of the Sierra del Brezo (Marín et al., 1996), but a re-examination of the locality involved has shown that the fossils identified by Villa (in Marín et al., 1996) originated from the underlying Valdeteja Limestone Formation (Wagner \& Winkler Prins, 1997, 2000).

The facies characteristics of the Perapertú Formation are those of an unstable marine basin, primarily a mud en-

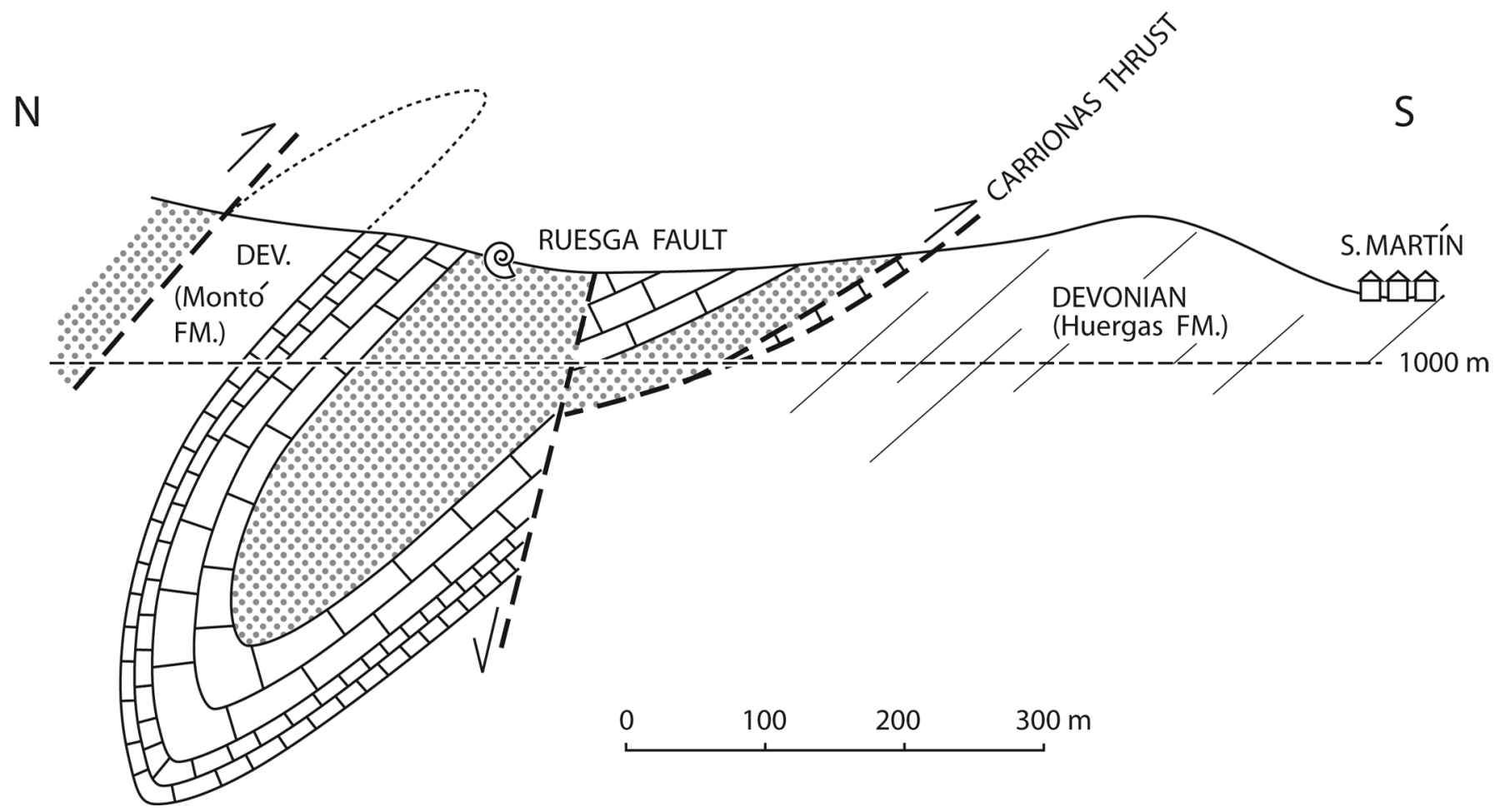

Figure 4. Section across the map of figure 3, coincident with goniatite locality no 9795 (RHW/CFWP). 
vironment with upstanding fault-bounded platform areas which accumulated limestones. The platform margins were subject to syn-sedimentary faulting since they released carbonate debris flows as well as major limestone blocks which are incorporated as megabreccias in the surrounding mud basin. A maximum development of $300 \mathrm{~m}$ of platform limestone is registered in an area South of the mountain pass of Piedrasluengas (van de Graaff, 1971), which is West of Peña Labra (Fig. 1). The Piedrasluengas Limestone, which was regarded originally as a separate formation (Brouwer \& van Ginkel, 1964), was dated as Early Moscovian on foraminiferal evidence (van Ginkel, 1965). This limestone occupies the upper part of the Perapertú Formation. A more substantial list of foraminifera, including both fusulinoideans and small foraminifera, as identified by Z.S. Rumyantseva, was published by Wagner $\&$ Bowman (1983: table 4) from a number of limestone localities in the general vicinity of Perapertú village, West of the Stephanian B outlier of Peña Cildá (Fig. 1). These were generally attributed to the Vereisky Horizon of the Moscovian Stage. The foraminifera of the Perapertú Formation range in Russia from Late Bashkirian to Early Moscovian (Einor, 1996: fig. 25) with one subspecies (Profusulinella rhombiformis nibelensis Rauser-Chernousova, 1951) being confined to the Late Bashkirian; whereas several species occur both in the Late Bashkirian and Vereisky [Profusulinella pararhomboides Rauser-Chernousova \& Beljaev, 1936, Pr. ex. gr. rhomboides (Lee \& Chen, 1930)]. Many others occur only in the Vereisky or later deposits (e.g. Pr. prisca (Deprat, 1912), Schubertella pauciseptata Rauser-Chernousova, 1938, Sch. obscura Lee \& Chen, 1930, Pseudostaffella subquadrata Grozdilova \& Lebedeva, 1950, Aljutovella distorta Leontovich, 1951, and A. subaljutovica Safonova, 1951); a few are even restricted to the "Tsninsky" (Pr. paratimanica Rauser-Chernousova, 1951, A. complicata Safonova, 1951). A late Vereisky age seems the most likely (E. Villa, pers. comm., August 2005).

The foraminiferal faunas are not the only marine faunas of stratigraphic significance encountered in the Perapertú Formation. From shales immediately below the Piedrasluengas Limestone a small goniatite fauna was figured and described by Wagner-Gentis (1985), who compared it with Lower Pennsylvanian Atokan faunas from North America. A revision of the same specimens by J. Kullmann (this paper) suggests the Diaboloceras-Winslowoceras Genozone of Early Moscovian age, which is in substantial agreement with the original age identification. Another small goniatite fauna was found more recently at $14 \mathrm{~m}$ above the base of the Perapertú Formation in folded strata almost immediately North of the Ruesga Fault in a locality at c. $500 \mathrm{~m}$ North of San Martín de los Herreros (Figs 3, 4 and 5). This fauna, which is figured and described in the present paper, appears to be marginally older than that below the Piedrasluengas Limestone, since it con- tains Branneroceras which characterises the higher Morrowan in North America and ranges from Late Bashkirian to earliest Moscovian in Russia and the Ukraine. The slight difference in age between these two goniatite assemblages agrees with the different positions within the Perapertú Formation.

\section{TIME-EQUIVALENT FORMATIONS}

(R.H. Wagner \& C.F. Winkler Prins)

In other parts of the Cantabrian Mountains (i.e. the Asturian-Leonese realm, as meant by Wagner \& Winkler Prins, 2000) the time-equivalent sediments to the Perapertú Formation of the Palentian Domain (North of the Carrionas/Ruesga fault trace) are first of all the highest part of the Valdeteja Limestone Formation (in those places where this formation with a diachronous top is developed in maximum thickness), and part of the overlying San Emiliano

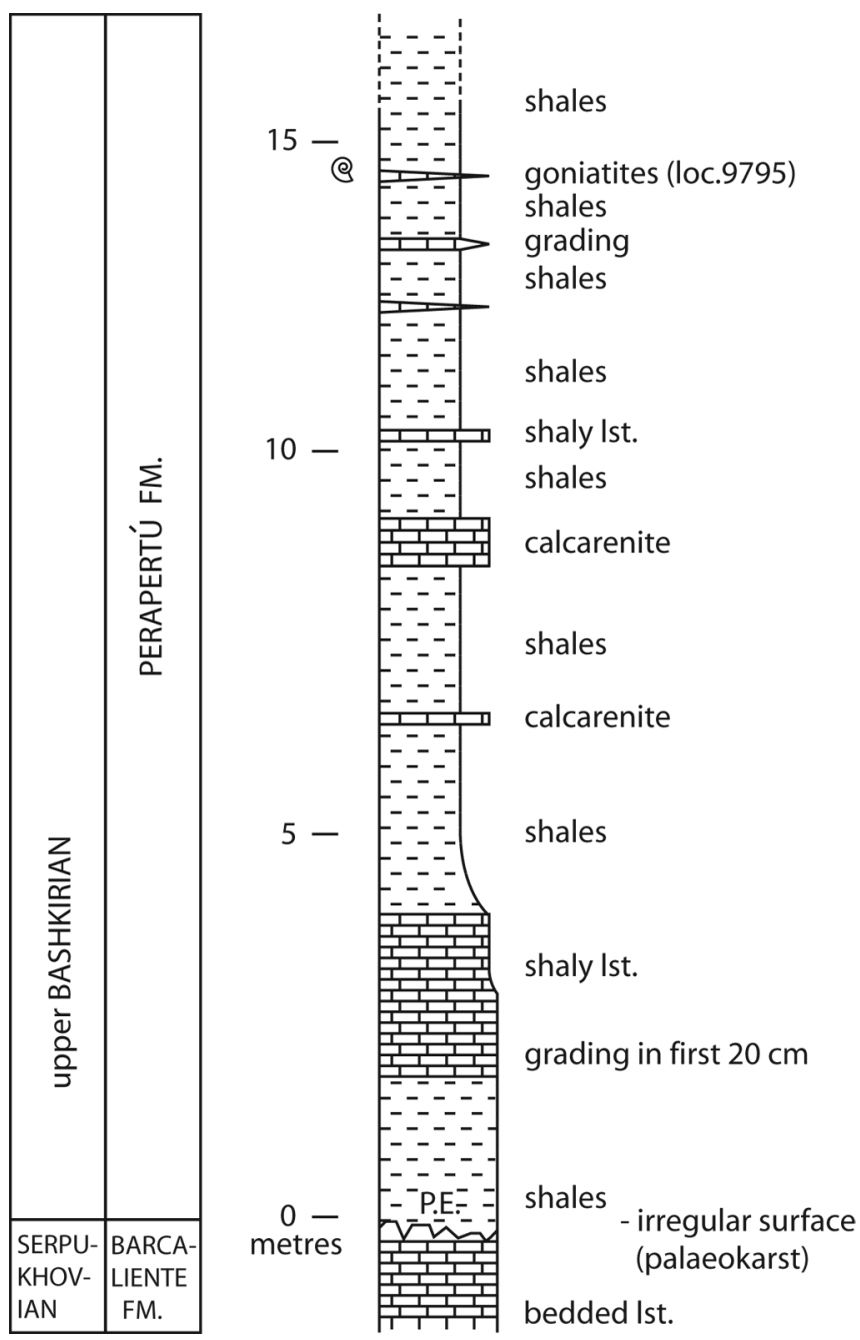

Figure 5. Section of the basal part of the Perapertú Formation at the collecting locality ${ }^{\circ} 9795$ (compare Figs 3 and 4) (RHW/CFWP). P.E. poorly exposed. 
Formation; furthermore, the condensed Ricacabiello Formation, and the lower parts of the Lena Formation and the Cuera Limestone.

The Valdeteja Limestone Formation generally belongs to the Upper Bashkirian, and reaches into Lower Moscovian (including the Asatausky - see below) in some sections (Villa, 1982; Villa et al., 2001). Locally, it is confined to the Bashkirian, e.g. in the Sierra del Brezo (Wagner \& Winkler Prins, 2000: 396), the Sierra del Sueve (Villa, 1989) and at Latores (Martínez Chacón \& Winkler Prins, in press). The overlying San Emiliano Formation, with a diachronous base, ranges from Upper Bashkirian to Lower Moscovian in the San Emiliano type area (Bowman, 1985; Carballeira et al., 1985; van Ginkel \& Villa, 1996). The Villamanín beds of the Bernesga Valley section in northern León may be largely equivalent to the highest (Candemuela) member of the San Emiliano Formation, being of Vereisky age (op. cit.), and thus correspond in age to the Perapertú Formation.

The Ricacabiello Formation (Martínez-Chacón et al., 1985) is a lateral equivalent of the Valdeteja Formation and also corresponds to the Bashkirian, reaching into Moscovian. The Lena Formation of the Central Asturian Coalfield is largely equivalent to the San Emiliano Formation (Leyva et al., 1985). The Cuera Limestones of eastern Asturias (Villa et al., 2000: 8) comprise the Valdeteja Formation in their lower part, but continue upwards into the Upper Moscovian. This is the general pattern of continual limestone deposition in the foreland area of the CantabricAsturian orogen.

\section{DATING OF BARCALIENTE/PEÑA, PE- RAPERTÚ, AND CARMEN FORMATIONS}

\author{
(R.H. Wagner, C.F. Winkler Prins \& J. Kullmann)
}

Conodont and foraminiferal evidence is available for the Barcaliente Formation (and the still undescribed Peña Formation which is its lateral equivalent in most of the Palentian Domain - Wagner \& Winkler Prins, in prep.) as well as for the Perapertú Formation. The type section of the Peña Formation in Peña Santa Lucía, West of Santibañez de Resoba (Fig. 1), has yielded conodont faunas of Serpukhovian age in the lower part which follows in conformable succession upon the Carrión Limestone unit (in the same thrust slice) which Nemyrovska (2005) has determined as ranging from Viséan to lower Serpukhovian. Foraminiferal faunas from the higher part of the Peña Formation have been studied by E. Villa (pers. comm., 13/02/1996), who identified Lower Bashkirian, probably equivalent to Siuransky Horizon. This agrees with the results obtained by T. Nemyrovska (pers. comm.) from a section of the laterally equivalent Barcaliente Limestone at La Lastra village, corresponding to the first thrust slice North of the Carrionas/Ruesga fault trace, where succes- sive conodont faunas show ages ranging from Serpukhovian to Early Bashkirian, the latter only in the top part of the c. $80 \mathrm{~m}$ thick limestone section. The thicker Peña Formation, as developed in thrust slices North of La Lastra, is clearly a time equivalent of the Barcaliente Formation. An irregular erosional contact (presumed palaeokarst) is present between the Barcaliente and Perapertú formations at La Lastra village. No Perapertú Formation has been found in the thrust slice represented at Peña Santa Lucía, where the Peña Formation is the highest stratigraphic unit recognised.

A small goniatite fauna collected from locality $\mathrm{N}^{\circ} 9795$ at $14 \mathrm{~m}$ above the base of the Perapertú Formation at $\mathrm{c}$. 500 m North of San Martín de los Herreros (Figs 3 to 5), where an erosional contact is observed with underlying Barcaliente/Peña Formation, is most likely Late Bashkirian in age on the basis of Branneroceras being present. This genus also characterises the Bloyd (upper Morrow) in the Ozark Uplift of Arkansas/Oklahoma (McCaleb, 1968). Another small goniatite fauna was described by WagnerGentis (1985) from just below the Piedrasluengas Limestone, a $300 \mathrm{~m}$ thick unit of platform limestone at the top of the Perapertú Formation. A revision of the original material, kept in the Senckenberg Museum in Frankfurt-amMain, resulted in the following list (J.K. det.): Boesites sp., Diaboloceras sp., Phaneroceras gandli Wagner-Gentis, 1985, Phaneroceras? sp., Proshumardites? sp. vel Deleshumardites? sp. This is an assemblage belonging to the Diaboloceras-Winslowoceras Genozone, of Early Moscovian age (also Atokan in the American chronostratigraphic terminology). It thus appears that the Perapertú Formation spans both the Branneroceras and Diaboloceras-Winslowoceras zones, and ranges in age from Late Bashkirian to Early Moscovian.

The foraminiferal faunas identified by S.Z. Rumyantseva (in Wagner \& Bowman, 1983) from limestones in the Perapertú Formation near San Martín de Perapertú have been attributed to the Lower Moscovian Vereisky Horizon (with one locality suggesting Kashirsky), a conclusion which agrees with the dating of the Piedrasluengas Limestone, exposed more to the North in the same province of Palencia. The full thickness of the Perapertú Formation has not been ascertained, but it is probably in excess of $500 \mathrm{~m}$.

The $300 \mathrm{~m}$ thick Piedrasluengas Limestone (Brouwer \& van Ginkel, 1964; van de Graaff, 1971), in the top part of the Perapertú Formation, is overlain by mudstones with conglomerate lenses in the area South of the Piedrasluengas mountain pass. These overlying deposits are ascribed to the Carmen Formation, the highest stratigraphic unit in the pre-Curavacas succession. This formation, with an recorded thickness of at least $1,100 \mathrm{~m}$ in northern Palencia (Wagner et al., 1984), comprises shales alternating with generally turbiditic sandstone beds and also contains quartzite conglomerate lenses representing coastal material 
which has been slid into the marine basin. The Piedrasluengas Limestone passes northwestwards from the province of Palencia (Castilla) into neighbouring Cantabria (formerly Santander province) where the overlying conglomeratic deposits of the Carmen Formation continue in the direction of Dobres (Fig. 1). These were assumed to have yielded the floral remains reported by Wagner (1959, 1962) and Wagner \& Álvarez-Vázquez (1995), but recent work has shown that these plant impressions of Langsettian age originated from the Curavacas Formation. This post-orogenic formation, belonging to a later episode in the tectono-stratigraphic history of the region, overlies the structures involving the Carmen Formation with total unconformity.

This leaves the Carmen Formation with less direct evidence of stratigraphic age. The palaeontological information in this respect is as follows. The bivalve Pterinopecton rhytmicus Jackson, 1927 was recorded by Kanis (1956) from a locality at $1 \mathrm{~km}$ West of Valsadornín (Palencia). According to the geological map published by Wagner et al. (1984), this locality lies in the Carmen Formation. Kanis (1956), who did not figure the specimen in question, suggested that it indicated a mid-Namurian age. Kanis also collected a drifted plant remain from strata of the same formation at $500 \mathrm{~m} \mathrm{NW}$ of Cervera de Pisuerga, also in northern Palencia. This specimen was figured and described by Wagner (1962: pl. 29, figs 1, 1a) as Sphenopteris stockmansii. Although assumed to be of early to mid-Namurian age (op. cit.), the total range of this species may be more extensive. Another palaeobotanical record, Calamites vandergrachtii Kidston \& Jongmans, 1915 (Wagner et al., 1984: 33) is devoid of stratigraphic interest. Likewise, a specimen of Lepidophloios laricinus Sternberg, 1825 found in turbiditic sandstone of the Carmen Formation immediately North of the Ruesga Fault, North of the Ruesga Dam, is lacking in stratigraphic importance. More relevant is the find of a pinnule of Linopteris in fine-grained sandstone of the Carmen Formation overlying limestone of the Genicera Formation in the head of the Revilla Nappe near Barruelo de Santullán (Wagner, 1971: 443). This genus does not seem to occur below the Westphalian in Europe. Even more important is the record of a Westphalian A (Langsettian) microflora from the upper part of the Carmen Formation in its type section near Vallespinoso de Cervera (Dorning in Wagner et al., 1984: 33).

A Langsettian age for the entire Carmen Formation, a turbiditic unit of at least a thousand metres thickness should probably be interpreted more specifically as early Langsettian, in view of the (late?) Langsettian age of the overlying Curavacas Formation. Wagner \& Álvarez-Vázquez (1995) accepted that the basal portion of the Curavacas Conglomerate Formation belonged to the (highest?) Langsettian, as Stockmans \& Willière (1965) had determined previously. Recent work in the vicinity of Dobres-Cucayo (Liébana region of Cantabria) strongly supports a Langsettian age for the lowermost part of the Curavacas Formation.

An early Langsettian age for the Carmen Formation suggests that the underlying Perapertú Formation probably straddles the Namurian-Westphalian boundary.

The mainly Lower Moscovian Perapertú Formation may thus be regarded as belonging to either the upper Namurian (Yeadonian) or lowermost Langsettian. This correlation which was suggested already by Wagner \& Bowman (1983) is not that which is commonly accepted in the literature. In fact, the authors usually place the base of the Moscovian at a level corresponding to upper Langsettian or even lower Duckmantian, if not higher (see the correlation table in Heckel, 2004, where the base of the Moscovian is placed quite high in the Westphalian). This will be discussed in the next chapter.

\section{MARINE-TERRESTRIAL CORRELATIONS}

(R.H. Wagner, C.F. Winkler Prins \& J. Kullmann)

The higher Carboniferous (Pennsylvanian) of the Cantabrian Mountains is predominantly marine with a Palaeotethyan connection which allows direct correlation with Russia and the Ukraine. Marine faunas of the American Midcontinent are comparable but not wholly identical, whilst the occasional marine bands present as marine incursions in the area of the Paralic Coal Belt of northern Europe and the Appalachians in North America show more limited faunal compositions. Oddly enough, the Bashkirian/Moscovian ammonoids (Nassichuk, 1975) and brachiopods (Martínez Chacón \& Bahamonde, in press; Winkler Prins, in press) show very close resemblances with those of Ellesmere Island in Arctic Canada.

The North European area has relied to a large extent on a succession of eustatic transgressions for long-distance correlation (with individual faunas marking the transgressions) as well as on terrestrial floral zonation. Eustatic transgressions are difficult to recognise in the tectonically much more mobile setting of the Pennsylvanian sediments in the Cantabric-Asturian arcuate fold belt of NW Spain, but marine faunal zones and terrestrial floral zones can both be distinguished due to the abundant fossil remains found in this region.

In northern Palencia, the total unconformity between post-orogenic deposits of the Curavacas Conglomerate Formation and the various formations involved in thrust slices and high-level nappe structures underlying this conglomerate formation provides a ceiling to the ages of the underlying formations. This includes the Perapertú Formation, which is therefore earlier in age than the (late) Langsettian as determined for the lowermost deposits of the Curavacas Formation on the basis of floral assemblages. Turbiditic and deltaic deposits overlying the Cura- 
vacas Formation range up into lower to mid-Westphalian D (= Asturian Substage). The formations below the Curavacas Formation, i.e. the Barcaliente/Peña, Perapertú and Carmen formations are highly significant for the international correlation between the East European Tethyan area and the West European region. This matter was addressed already by Wagner \& Bowman (1983), but further precision in the determination of floral remains in Wagner \& Álvarez-Vázquez (1995) (partly based on new material) and the finds of small goniatite faunas as reported here, provide additional information to the foraminiferal and conodont faunas mentioned in 1983.

International correlations involving different faunas from Russia/Ukraine and North America as published most recently, need to be referred to, albeit briefly. Groves (1988: fig. 3) correlated the Late Bashkirian and Early Moscovian with the late Atokan on fusulinacean faunas, but later (Groves et al., 1999) considered the top Bashkirian to correlate with the lower Atokan. Nemyrovska \& Alekseev (1995: 116), discussing conodont and foraminiferal evidence, stated that the upper boundary of the Bashkirian did not seem to be very clear. Indeed, these authors correlated the highest Bashkirian (Asatausky) in the Urals with the Vereisky of the Moscow Syneclise on conodont evidence, thus lowering the base of the Moscovian in the Donets Basin to the base of limestone $\mathrm{I}_{2}$. Vachard \& Maslo (1996: 367-369), stated that at least limestones $\mathrm{K}_{1}$ and $\mathrm{K}_{2}$ should be included in the Moscovian, but that the Asatausky (uppermost Bashkirian) would seem to correspond to the Vereisky (lowermost Moscovian), as Nemyrovska \& Alekseev (1995) had suggested, thus placing the boundary at the base of Limestone $\mathrm{I}_{2}$ of the Donbass. Since the basal part of the Vereisky in the Moscow Syneclise is nonmarine (Einor, 1996), and thus without foraminiferal faunas, the actual base of the Moscovian may be situated even lower in the Upper Bashkirian. These non-marine deposits were used to explain the apparently anomalous mixed Bashkirian-Moscovian foraminiferal fauna which was described by Granados et al. (1985) from the Central Asturian Coalfield in NW Spain (compare Villa et al., 2001: 82). A megafloral analysis by Fissunenko \& Laveine (1984) suggested that the base of the Moscovian would most likely correspond to the Westphalian A/B (= Langsettian/Duckmantian) boundary, and the ranges of floral elements in the Donbass (chart published by Fissunenko in "The Carboniferous of the World" vol. III - Einor, 1996: fig. 28) seem to support this assertion. Fissunenko \& Laveine (1984: 98, table 3) placed the Westphalian B/C (= Duckmantian/Bolsovian) boundary higher in the Donbass succession, viz. somewhere between limestones $\mathrm{K}_{3}$ and $\mathrm{K}_{7}$, most likely at the base of limestone $\mathrm{K}_{7}$, when taking also the palynological evidence into account. The correlation of the Bashkirian/Moscovian boundary according to Vachard \& Maslo (1996) and Fissunenko \& Laveine (1984) does not tie in exactly with our data. More exhaustive information on the Donbass would be useful, with particular regard to the plant megafossils which are in need of a modern revision. It is noted that in recent papers, Nemyrovska (1999: 49) and Alekseev et al. (2004: fig. 1) revert to a now obsolete correlation of the Bashkirian/Moscovian boundary with that between Duckmantian and Bolsovian, as suggested by Stepanov et al. (1962). They placed it, respectively, at the base of Limestone $\mathrm{K}_{3}$ and of Limestone $\mathrm{K}_{2}$. Finally, it is observed that Izart et al. (1996: 192, table 1) placed the Bashkirian/Moscovian boundary as determined in the Donets Basin, in the upper Duckmantian Substage using foraminiferal and palynological evidence. However, they position the boundary at the base of their Unit SM1, i.e. between limestones $\mathrm{K}_{1}$ and $\mathrm{I}_{4}$. All these different opinions leave considerable latitude for discussion. Part of the problem, of course, seems to lie with the likelihood that an overlap exists between the Upper Bashkirian and the Lower Moscovian in their respective stratotypes.

\section{EARLY PENNSYLVANIAN AMMONOID FAUNAS AS RECORDED IN THE CANTABRIAN MOUNTAINS}

\author{
(J. Kullmann)
}

Lower Pennsylvanian deposits are widespread in the Cantabric-Asturian arcuate fold belt and some outcrops have yielded ammonoids. In most cases they are poorly preserved, without visible suture lines. The fragmentary state of the shells usually precludes a conclusive determination.

Ammonoid faunas with Proshumardites RauserChernousova, 1928, Phillipsoceras Ruzhentsev \& Bogoslovskaya, 1975 (= Reticuloceras Bisat, 1924) and Ramosites Ruzhentsev \& Bogoslovskaya, 1969 indicate undoubtedly an earliest Bashkirian age (Kullmann, 1973, 1979). These occur in shaly beds overlying the Barcaliente Limestone Formation, at Santa Olaja de la Varga (León province), and at the Porma Reservoir near Boñar (León). Similar small faunas have been described from a higher level, also in the province of León, by Wagner-Gentis (in Moore et al., 1971). She originally recorded Retites McCaleb, 1964, an identification which was changed later to Branneroceras Plummer \& Scott, 1937 (Wagner-Gentis in Wagner \& Bowman, 1983: 141). These were obtained from strata of Marsdenian age as determined by palynology (Neves in Moore et al., 1971). Branneroceras was also recorded from overlying sediments of early Westphalian A (= Langsettian) age (Wagner-Gentis in Moore et al., 1971). This age, based on palynology (op. cit.), was later confirmed by Horvath (in Villa et al., 1988). The same strata also yielded Upper Bashkirian foraminifera (op . cit.). A direct correlation between early Langsettian and Late Bashkirian is therefore suggested. Schmidt (1955) fig- 
ured and described a Paralegoceras percostatum Schmidt, 1955 from a succession of Langsettian coal-bearing strata at La Camocha, near Gijón, Asturias (Wagner \& ÁlvarezVázquez, 1995). This species was later referred tentatively to Axinolobus by McCaleb (1968). Comparison was made with the Atokan of North America and with Westphalian faunal elements in Algeria.

A goniatite find in mudstones overlying the Valdeteja Limestone Formation was mentioned but not figured, as Proshumardites morrowanus Gordon, 1964, from a locality North of Villafría on the southern flank of the Sierra del Brezo (Palencia) (C.H.T. Gentis in Wagner \& Winkler Prins, 2000: 388). This unfigured specimen seems to have been lost. Additional remains from this locality, lodged in the collections of the Geology Department at Oviedo University, are heavily crushed shells which might belong to Proshumardites or Deleshumardites? sp. indet., suggesting either Late Bashkirian or Early Moscovian.

The small fauna from North of the Ruesga Fault, at c. 500 m North of San Martín de los Herreros, from beds low in the Perapertú Formation (loc. 9795 - see Figs 3 to 5), seems to be slightly older than the Piedrasluengas fauna higher in this formation, because it contains Branneroceras which starts in the Late Bashkirian and disappears in the Early Moscovian (N.B. these are probably partly equivalent ages.). Representatives of Branneroceras are regarded in North America as index fossils of the lower Bloyd of the Ozark Uplift (McCaleb, 1968). Deleshumardites and related forms are longer ranging; being known from Arnsbergian (Upper Serpukhovian, Mississippian Subsystem) until at least Langsettian (Pennsylvanian Subsystem) in Europe and Asia, and Atokan (Pennsylvanian) in North America. Both faunal elements, Deleshumardites and Branneroceras, were globally distributed in early Pennsylvanian times and document the close connection of marine habitats during Late Bashkirian/Early Moscovian (Langsettian) and Bloydian (late Morrowan) times.

\section{CONCLUSIONS}

\section{(J. Kullmann, R.H. Wagner \& C.F. Winkler Prins)}

A newly discovered ammonoid fauna at $14 \mathrm{~m}$ above the base of the Perapertú Formation in the Palentian facies and structural domain in northern Palencia shows that the Upper Bashkirian may be involved in the lowermost part of this formation. Most of the Perapertú Formation corresponds to Lower Moscovian Vereisky Horizon however (which overlaps with the highest Bashkirian of Bashkiria, South Urals). This correlates with lowermost Langsettian and/or upper Yeadonian of the West-European chronostratigraphic classification, on the evidence presented. The base of the Moscovian Stage would thus seem to coincide approximately with the base of the Westphalian regional Stage, or even a little below, reaching into highest Namurian.

\section{SYSTEMATIC DESCRIPTION OF AMMONOIDS (Figs 6-8)}

\author{
(J. Kullmann)
}

Locality at c. 500 m North of San Martín de los Herreros (Palencia)

The ammonoids in this locality ( $\left.\mathrm{N}^{\circ} 9795\right)$ low in the Perapertú Formation (Fig. 5) are, on the whole, poorly preserved. They were imbedded in shales with fine-grained siliciclastic material and occur as crushed shells which only rarely display the suture lines. Precise measurement of the shell dimensions is impossible, and the ornamentation is difficult to observe. Nevertheless, the preservation allows an indication of age and facies conditions, and this permits a comparison with the stratigraphic age of the locality below the Piedrasluengas Limestone higher in the Perapertú Formation, further North in the same province of Palencia.

The specimens are deposited in the "Nationaal Natuurhistorisch Museum" (National Museum of Natural History) in Leiden (The Netherlands). The prefix RGM refers to the former "Rijksmuseum van Geologie en Mineralogie". Conventional abbreviations are: $\mathrm{D}=$ diameter, $\mathrm{Wh}=$ whorl height, $\mathrm{Ww}=$ whorl width, $\mathrm{U}=$ umbilicus

Tolibia de Abajo (León province); Genicera (= Alba) Limestone Formation

One new species is described primarily from this locality in northern León, at Tolibia de Abajo, with a different age (Late Mississippian). Specimens are lodged in the Geology Departments of the universities at Tübingen and Münster, Germany.

Order GONIATITIDA Hyatt, 1884

Superfamily Goniatitoidea Hyatt, 1884

\section{Family Delepinoceratidae Ruzhentsev, 1957}

A close relationship exists between the delepinoceratids with a tendency towards trifurcate ventral and adventitious lobes (i.e. subfamily Delepinoceratinae Ruzhentsev, 1957), and the dombaritids with only the adventitious lobe being trifurcate (subfamily Dombaritinae subfam. nov.). Representatives of both subfamilies occur jointly in Late Viséan and Early Serpukhovian faunas. The Dombaritinae are traditionally regarded as the source group of the Agathiceratoidae Arthaber, 1911, which are clearly distinguished by the threefold subdivided adventitious lobe with three long and independent parts. The Agathiceratoidea show in addition the tendency to develop a retrochoanitic siphuncle, whereas the Goniatitoidea display usually rather short septal necks.

\section{Subfamily Dombaritinae Kullmann, subfam. nov.}

Diagnosis: Delepinoceratidae with a tendency towards trifurcation of the adventitious lobe only. 
Constituent genera: Dombarites Librovitch, 1957; Proshumardites Rauser-Chernousova, 1928; Deleshumardites Kullmann, gen. nov.

Range: Mississippian (Late Viséan-Serpukhovian, Chesterian), Pennsylvanian (Bashkirian, ?Moscovian, MorrowanAtokan) in Europe, Asia, North Africa, North America.

\section{Deleshumardites Kullmann, gen. nov.}

Type-species: Proshumardites delepinei Schindewolf, 1939: 429.

1937 Proshumardites Rauser-Chernousova; Delépine \& Menchikoff, 78.

1939 Proshumardites Rauser; Schindewolf, 429.

pars 1962 Proshumardites (Proshumardites) Rauser-Chernousova; Kullmann, 68.

pars 1971 Pericleites Renz; Ruzhentsev \& Bogoslovskaya, 236.

pars 1971 Proshumardites Rauser-Chernousova; Ruzhentsev \& Bogoslovskaya, 240.

Derivatio nominis: Named in honour of Monseigneur Gaston Delépine, who described and figured the group under consideration for the first time (Delépine \& Menchikoff, 1937: 78, i.e. Proshumardites Karpinskyi, text-fig. 4, pl. 5, figs 2-3).

Additional species: Deleshumardites cantabricus sp. nov., Proshumardites aequalis Nassichuk, 1975, Pr. morrowanus Gordon, 1964, Pr. primus Plummer \& Scott, 1937, and Shumardites Keideli Leuchs, 1919.

Diagnosis: Dombaritinae with thick discoidal conch and narrow umbilicus. No triangular inner whorls. Ornamentation consists of fine growth lines and usually also prominent lirae. Ventral lobe relatively wide, median saddle at least half the height. Ventrolateral saddle acute, subacute or narrowly rounded. Adventitious lobe very wide, subdivided into three small lobes, the middle lobe being longer and acute, the outer ones smaller and acute or narrowly rounded. Sutural formula: $\left(\mathrm{E}_{1} \mathrm{E}_{\mathrm{m}} \mathrm{E}_{1}\right)\left(\mathrm{A}_{\mathrm{v}} \mathrm{A}_{\mathrm{m}} \mathrm{A}_{\mathrm{d}}\right)$ : UI or $\left(\mathrm{V}_{1} \mathrm{~V}_{1}\right) \mathrm{L}_{2} \mathrm{~L}_{1} \mathrm{~L}_{2}$ : ID.

Comparisons: The new genus is distinguished from Proshumardites by the wide adventitious lobe and its three comparatively wide and long subdivided parts; especially the lateral parts are considerably larger in Deleshumardites gen. nov. Agathiceras Gemmellaro, 1887 displays three equally long parts of the adventitious lobe and possesses usually a retrochoanitic siphuncle. The tridentate adventitious lobe of Proshumardites (see P. karpinskii, RauserChernousova, 1928 (Fig. 6b, 8a), P. principalis Ruzhentsev \& Bogoslovskaya, 1971 (Fig. 6a), P. uralicus Librovitch, 1941 [=?Pericleites pilatus Ruan, 1981; = P. wocklumerioides Kullmann, 1962] (Fig. 6c) shows a rather long and acute middle part; the lateral parts are small and short, with acute, hook-like tips.

Occurrence: Arnsbergian (Upper Serpukhovian, Mississippian)-Langsettian, ?Bolsovian (Upper Bashkirian, Moscovian), Bloydian (upper Morrow)-Atokan (Pennsylvanian). Algeria, Canada (Arctic Archipelago), Iran, Japan, Kazakhstan (South Urals, Tian Shan), Russian Federation (South Urals, Novaya Zemlya), Tajikistan, Uzbekistan, USA (Arkansas, Nevada, Oklahoma, Texas).

\section{Deleshumardites cantabricus Kullmann, sp. nov.} Figs $7 b, c, 8 b-f$

1958 Proshumardites aff. delepinei Schindewolf; Schindewolf \& Kullmann, 51.

1962 Proshumardites (Proshumardites) delepinei Schindewolf; Kullmann, 70, text-fig. 11 b-c, pl. 5, figs 1-5.

Holotype: GPIT Tübingen, No. Ce1206/258 (Figs 7c, 8c-d).
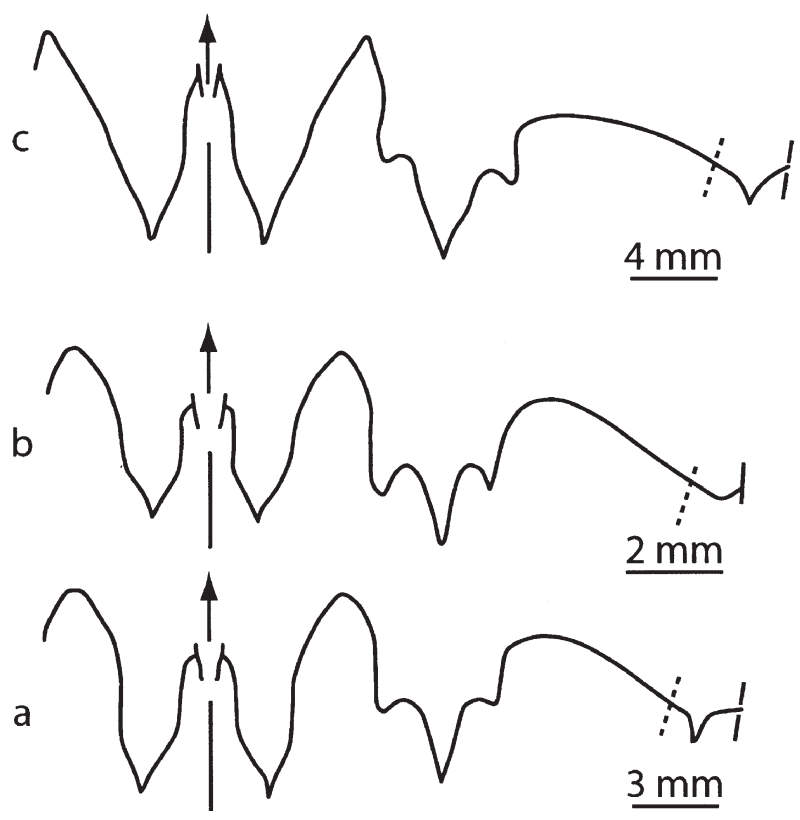

Figure 6. Suture lines of Proshumardites Rauser-Chernousova, 1928 (J.K.) a: Proshumardites principalis Ruzhentsev \& Bogoslovskaya, 1971, PIN 455/28196, paratype, South Urals, Bashkortostan, upper Eumorphoceras Zone, $\mathrm{E}_{2}$, Arnsbergian, Mississippian (from Ruzhentsev \& Bogoslovskaya, 1971, text-fig. 53b), x 3. b: Proshumardites karpinskii Rauser-Chernousova, 1928, PIN 455/28786, South Urals, Bashkortostan, lower Bashkirian, Pennsylvanian (after Ruzhentsev \& Bogoslovskaya, 1978, text-fig. 12b), x 5. c: Proshumardites uralicus Librovich, 1941, PIN 455/228051, South Urals, Bashkortostan, upper Eumorphoceras Zone, $\mathrm{E}_{2}$, Arnsbergian, Mississippian (after Ruzhentsev \& Bogoslovskaya, 1971, text-fig. 53b), x 2. 
Locus typicus/Stratum typicum: Tolibia de Abajo, province of León, uppermost Genicera (= Alba) Formation, upper Eumorphoceras Zone $\left(\mathrm{E}_{2}\right)$, Arnsbergian (Upper Serpukhovian, Mississippian).

Material: Holotype and about 20 specimens of the GPIT Tübingen 1206/119, 187, 189, 257-58, 262-63, 266, 270, D = 13-56 mm, 3 specimens of the GPI Münster L4016, L4018-19, L4035, $\mathrm{D}=9-19 \mathrm{~mm}, 1$ specimen RGM 343010, D = $13 \mathrm{~mm}$.

Diagnosis: Deleshumardites with strongly sinuous sides of the ventral and adventitious lobes, acute saddle in between. Median lobe exceeds slightly half the height of entire ventral lobe. No constrictions in adult stages. About 70-80 spiral lirae, stronger than growth lines.

Description: The outline of the bigger specimens is oval with a rather small umbilicus. The flanks are roundedly arched and pass continuously into the ventral side (Fig. 8c-f). The living chamber comprises about one whorl. There are four constrictions on parts corresponding to early stages. Growth lines can be observed only partly. The spiral ornamentation is slightly stronger than the growth lines. The tridentate adventitious lobe displays sinuously rounded sides. Its three portions are long, comparatively wide and acute.

The relationship of the new species to the type species is very close. The holotype of the latter which was described as Proshumardites Karpinskyi by Delépine \& Menchikoff (1937: 78, text-fig. 4, pl. 5, figs 2, 3) seems to have less sinuous sides of the ventral lobe (see Fig. 7d, e). The Uralian form described by Ruzhentsev \& Bogoslovskaya (1971, text-fig. 52b) as Pericleites atticus seems to be identical with regard to the reconstructed suture line of the type species (Fig. 7d, e). The specimen figured and described as Proshumardites delepinei by Ruzhentsev \& Bogoslovskaya (1971, text-fig. 53g; see Fig. 7f) shows a highly elevated median saddle, a subacute ventrolateral saddle and less sinuous sides of the adventitious lobe; it is presently regarded as a new species (Deleshumardites sp. nov. Kullmann). Deleshumardites morrowanus (Gordon, 1964) of the Bloyd in North America is also closely related. It can be distinguished from Deleshumardites cantabricus by the relatively wide and partly pouched prongs of its ventral lobe.

Occurrence: Tolibia de Abajo, province León, Playa de Carranques and Perlora (province Oviedo, Asturias), from grey or yellowish marly limestones or marls of the uppermost layers of the Genicera (= Alba) Formation, upper Eumorphoceras Zone ( $\mathrm{E}_{2}$ ), Mississippian; Perapertú Formation (lower part), at c. 500 m North of San Martín de los Herreros (province Palencia), Upper Bashkirian (either Yeadonian or lowermost Langsettian).
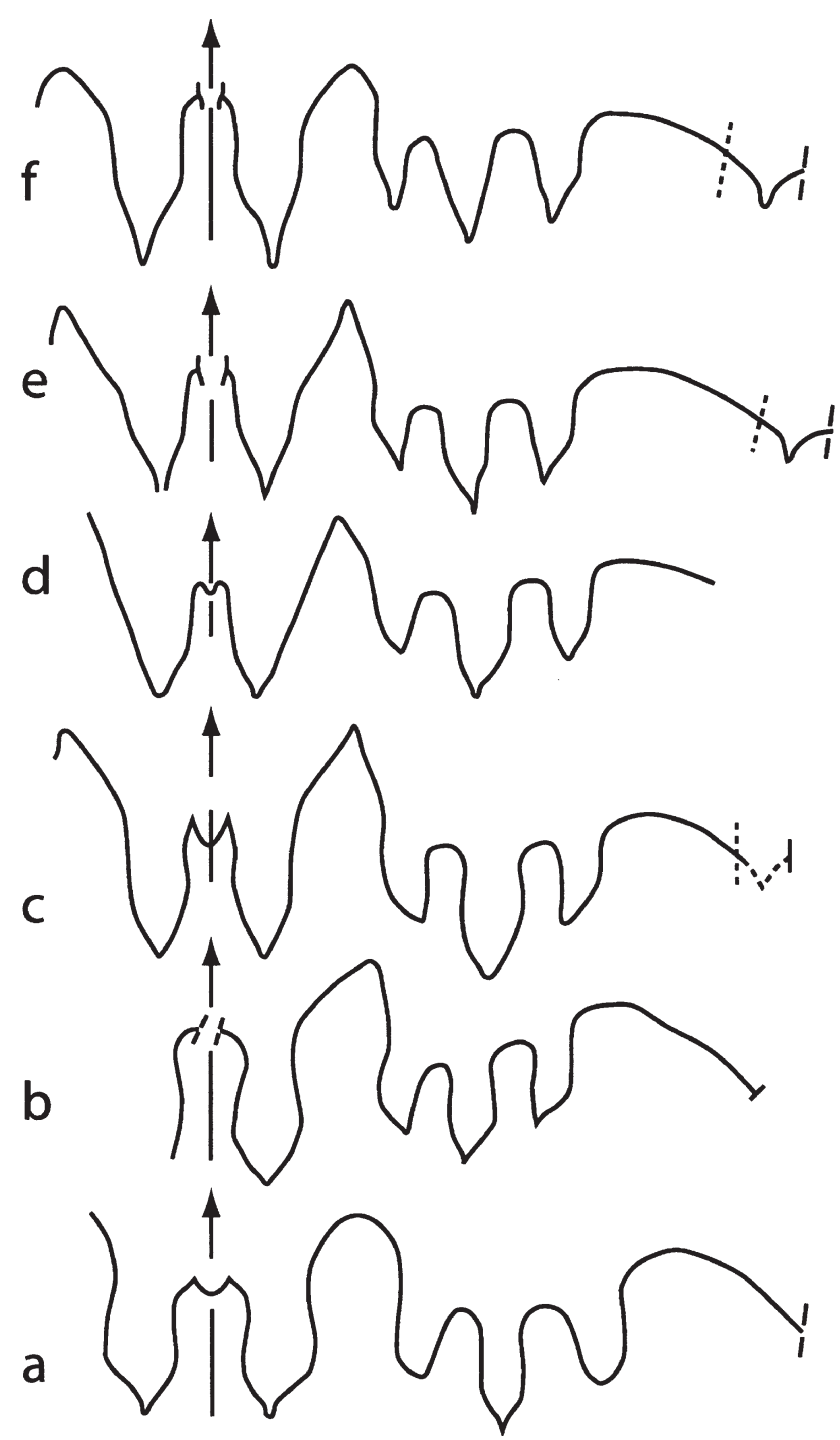

Figure 7. Suture lines of Deleshumardites Kullmann, gen. nov. (J.K.) a: Deleshumardites morrowensis (Gordon, 1964), hypotype, SUI 11675, Arkansas (USA), Bloyd Formation, Greers Ferry Dam, 3 miles NE of Heber Springs, Arkansas, Bloydian, late Morrowan, Pennsylvanian (after McCaleb, 1968, text-fig. 5A), x 4.1. b-c: Deleshumardites cantabricus Kullmann, sp. nov.; b, RGM 343010, Cantabrian Mountains, NW Spain, loc. 9795: c. 500 m South of San Martín de los Herreros (Palencia), Yeadonian or lowermost Langsettian, Pennsylvanian, x 6.6; c, holotype, GPIT Ce 1206/258, Cantabrian Mountains, NW Spain, Tolibia de Abajo (León), uppermost layers of the Genicera Formation, upper Eumorphoceras Zone (E ${ }_{2}$ ), Mississippian (after Kullmann, 1962, text-fig. 11c), x 3. d-e: Deleshumardites delepinei (Schindewolf, 1939); d, holotype (reconstructed in Schindewolf, 1939, text-fig. 2 after Delépine in Delépine \& Menchikoff, 1937, pl. 5, figs 1-5), Haci-Diab, AlgerianMoroccan border region, upper Eumorphoceras Zone, Arnsbergian, Mississippian, enlarged; e, PIN 455/28131, Verkhniaia Kardailovka, horizon 4, upper Eumorphoceras Zone, Arnsbergian, Mississippian (after Ruzhentsev \& Bogoslovskaya, 1971, described as "Pericleites atticus", text-fig. 52b), x 2.4. f: Deleshumardites sp. nov. Kullmann, PIN 455/28510, NE Krasno-Sakmarsk, South Urals, Orenburg County, upper Eumorphoceras Zone, Arnsbergian, Mississippian (after Ruzhentsev \& Bogoslovskaya, 1971, described as "Proshumardites delepinei", text-fig. 53g), x 2. 


\section{Deleshumardites sp.}

Material: Two fragmentary specimens, RGM 343011, D = c. $20 \mathrm{~mm}$, and RGM 343012, D = c. $10 \mathrm{~mm}$.

Description: The bigger specimen is a totally crushed shell that shows part of the spiral ornamentation and only a very small part of the suture line. The tridentate adventitious lobe has a comparatively big ventral lobelet, which is typical for Deleshumardites gen. nov.

The smaller specimen also shows a portion of the tridentate lobe of Deleshumardites gen. nov.
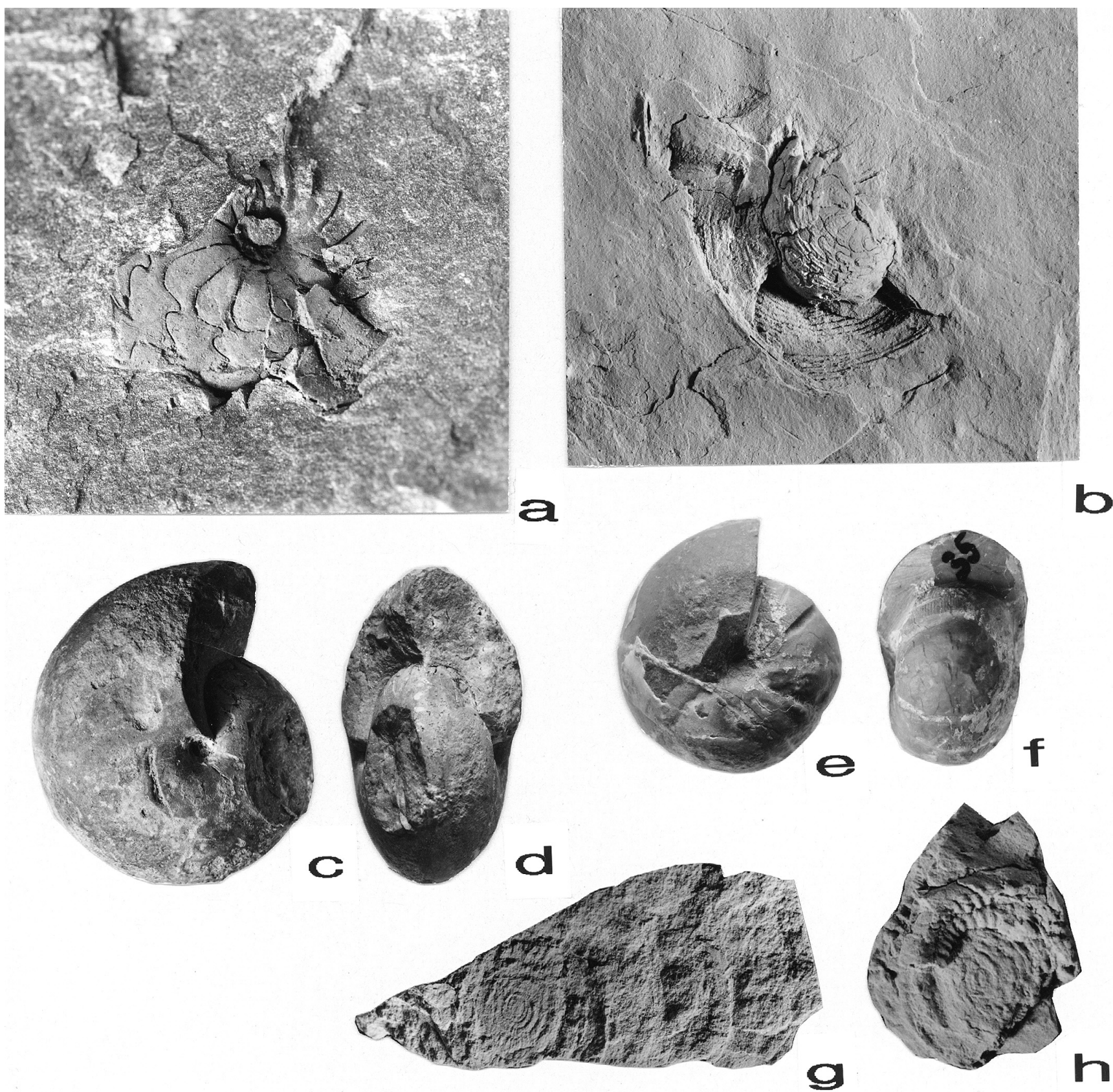

Figure 8. Photographic illustrations. (J.K.) a: Proshumardites karpinskii Rauser-Chernousova, 1928, GPIT 1432/1077, Asturreta, North of Eugui, Navarra, Spanish Pyrenees, Kinderscoutian, lower Bashkirian, Pennsylvanian (after Kullmann, 1973 : pl. I, fig. 4), x 5. b-f: Deleshumardites cantabricus Kullmann, sp. nov.; b, RGM 343010, loc. 9795, c. 500 m South of San Martín de los Herreros (Palencia), uppermost Bashkirian (Yeadonian or lowermost Langsettian), Pennsylvanian, x 2; c-d, Holotype, GPIT Ce 1206258, Tolibia de Abajo (León), uppermost layers of the Genicera Formation, upper Eumorphoceras Zone ( $E_{2}$ ), Mississippian; c, Side view; d, Front view, x 1; e-f, GPI Münster L 4035, Playa de Carranques, Perlora (Asturias), Genicera Formation, upper Eumorphoceras Zone ( $\left.\mathrm{E}_{2}\right)$, Mississippian; e, Side view; f, Front view, x 2. g-h: Branneroceras(?) sp.; g, RGM 343014; h, RGM 343013, external moulds, loc. 9795, c. 500 m South of San Martín de los Herreros (Palencia), uppermost Bashkirian (Yeadonian or lowermost Langsettian), Pennsylvanian, x 2. 
Occurrence: Perapertú Formation at c. 500 m North of San Martín de los Herreros (Palencia), Upper Bashkirian (either Yeadonian or lowermost Langsettian).

Superfamily Schistoceratoidea Schmidt, 1929

Family Schistoceratidae Schmidt, 1929

Branneroceras Plummer \& Scott, 1937

\section{Branneroceras (?) sp.}

Figs 8g-h

Material: Four fragments, RGM 343013-16, D = c. 11-15 $\mathrm{mm}$.

Description: Four small fragments may be assigned with some reservation to the genus Branneroceras. Three small specimens display well developed riblets at the umbilical portion of the flanks, disappearing ventrolaterally. The umbilical width of the better preserved specimens seems to have been at $\mathrm{D}=13.5 \mathrm{~mm}$ c. $8 \mathrm{~mm}$ and at D = $12 \mathrm{~mm} 6.5 \mathrm{~mm}$. A larger, fourth specimen shows a reticulate ornamentation without ribs. None display suture lines, and the tentative assignment to Branneroceras is based mainly on the kind of riblets and ornamentation common among branneroceratids. The early whorls can be observed in specimen RGM 343014 (Fig. 8g) which displays a rounded or slightly polygonal outline of the innermost whorls, which characterises Branneroceras, and which differs from the triangular early whorls of Diaboloceras.

Occurrence: Perapertú Formation, at c. 500 m North of San Martín de los Herreros (Palencia), Upper Bashkirian (either Yeadonian or lowermost Langsettian).

\section{ACKNOWLEDGEMENTS}

Mr S.B. Blankevoort (Nationaal Natuurhistorisch Museum Naturalis) is thanked for drawing figures 1-5. The third author (CFWP) gratefully acknowledges the A. Buitendijk Foundation for contributing to his travelling costs to Spain in order to finish fieldwork with the second author (RHW). The authors are also grateful for useful comments by the Referees, Drs L. Sánchez de Posada and J.L. Alonso. The pertinent remarks by Dr Sánchez de Posada are particularly appreciated. Dr. E. Villa is thanked for expert advice on foraminiferal faunas, and Dr. C. Álvarez-Vázquez for aid with the physical production of this paper. Helpful suggestions by the Editor, Dr. R. Gozalo, are also gratefully acknowledged.

\section{REFERENCES}

Alekseev, S.A., Goreva, N.V., Isakova, T.N. \& Makhlina, M.Kh. 2004. Biostratigraphy of the Carboniferous in the Moscow Syneclise, Russia. Newsletter on Carboniferous Stratigraphy, 22, 28-35.

Arthaber, G. von 1911. Die Trias von Albanien. Beiträge zur Paläontologie und Geologie Österreich-Ungarns und des Orients, 24, 169-177.
Bisat, W.S. 1924. The Carboniferous goniatites of the North of England and their zones. Proceedings of the Yorkshire Geological Society, 20, 40-124.

Bowman, M.B.J. 1985. The sedimentology and palaeogeographic setting of late Namurian-Westphalian A basin-fill successions in the San Emiliano and Cármenes areas of NW León, Cantabrian Mts, NW Spain. In: Papers on the Carboniferous of the Iberian Peninsula (Sedimentology, Stratigraphy, Palaeontology, Tectonics and Geochronology) (eds. M.J. Lemos de Sousa, \& R.H. Wagner). Anais da Faculdade de Ciências, Universidade do Porto, supplement vol. 64 (1983), 117-169.

Brouwer, A. 1964. Deux faciès dans le Dévonien des Montagnes Cantabriques méridionales. Breviora Geológica Astúrica, VIII, 3-10.

Brouwer, A. \& van Ginkel, A.C. 1964. La succession carbonifère dans la partie méridionales des Montagnes Cantabriques (Espagne du Nord-Ouest). Cinquième Congrès International de Stratigraphie et de Géologie du Carbonifère, Paris, 1963, Compte Rendu, I, 307-319.

Carballeira, J., Corrales, I., Valladares, I., Naval, A., Ruiz, F., Lorenzo, S., Martínez Chacón, M.L., Méndez, C., Sánchez de Posada, L.C. \& Truyols, J. 1985. Aportaciones al conocimiento de la estratigrafía de la Formación San Emiliano (Carbonífero, Cordillera Cantábrica) en su área-tipo. Dixième Congrès International de Stratigraphie et de Géologie du Carbonifère, Madrid, 1983, Compte Rendu, 1, 345-362.

Delépine, G. \& Menchikoff, N. 1937. La faune des schistes carbonifères à Proshumardites de Haci-Diab (Confins Algéro-marocains du Sud). Bulletin Société géologique de France, ser. 5, 7, 77-89.

Einor, O.L. (coord.) 1996. The former USSR. In: The Carboniferous of the World, III: The former USSR, Mongolia, Middle Eastern Platform, Afghanistan, \& Iran (eds. R.H. Wagner, C.F. Winkler Prins \& L.F. Granados). IUGS Publication, 33. Instituto Geológico y Minero de España, Madrid, 13-407.

Espina, R.G., Alonso, J.L. \& Pulgar, J.A. 1996. Growth and propagation of buckle folds determined from syntectonic sediments (the Ubierna Fold Belt, Cantabrian Mountains, N. Spain). Journal of Structural Geology, 18, 431-441.

Fissunenko, O.P. \& Laveine, J.P. 1984. Comparaison entre la distribution des principales espèces-guides végétales du Carbonifère moyen dans le bassin du Donetz (USSR) et les bassins du Nord-Pas-de-Calais et de Lorraine (France). Neuvième Congrès International de Stratigraphie et de Géologie du Carbonifère, Washington and ChampaignUrbana, 1979, Compte Rendu, 1 (Official Reports), 95-100.

Frankenfeld, H. 1984. Deckenbewegungen im Namur des östlichen Kantabrischen Gebirges und die damit verbundenen Vorstellungen über die Paläogeographie der Namur- und Prä-Namur-Schichten. Zeitschrift der Deutschen Geologischen Gesellschaft, 135 (Iberia Heft), 223-241.

Gemmellaro, G.G. 1887. La Fauna dei Calcari con Fusulina della Valle del Fiume Sosio. Fasciculo I. Palermo.

Ginkel, A.C. van 1965. Spanish Carboniferous fusulinids 
and their significance for correlation purposes. Leidse Geologische Mededelingen, 34, 171-225.

Ginkel, A.C. van \& Villa, E. 1996. Palaeontological data of the San Emiliano Formation (Cantabrian Mountains, Spain) and their significance in the Carboniferous chronostratigraphy. Geobios, 29, 149-170.

Gordon, M. 1964. Carboniferous Cephalopods of Arkansas. U.S. Geological Survey Professional Paper, 460, 322 pp.

Graaff, W.J.E. van de 1971. The Piedrasluengas Limestone, a possible model of limestone facies distribution in the Carboniferous of the Cantabrian Mountains. Trabajos de Geologia, 3 (The Carboniferous of Northwest Spain, vol. I), 151-159.

Granados, L.F., Solovieva, M.N., Reitlinger, E.A. \& Martínez Díaz, C. 1985. The Bashkirian-Moscovian boundary problem in the Asturias (Northwest Spain). Dixième Congrès International de Stratigraphie et de Géologie du Carbonifère, Madrid, 1983, Compte Rendu, 1, 27-34.

Groves, J. 1988. Calcareous foraminifers from the Bashkirian stratotype (Middle Carboniferous, South Urals) and their significance for intercontinental correlations and the evolution of the Fusulinidae. Journal of Paleontology, 62, 368-399.

Groves, J., Nemyrovska, T.I., \& Alekseev, A.S. 1999. Correlation of the type Bashkirian Stage (Middle Carboniferous, South Urals) with the Morrowan and Atokan Series of the midcontinental and western United States. Journal of Paleontology, 73, 529-539.

Heckel, P.H. 2004. Chairman's column. Newsletter on Carboniferous Stratigraphy, 22, 1-3.

Hyatt, A. 1884. Genera of fossil cephalopods. Boston Society of Natural History, Proceedings, 22, 253-338.

Izart, A., Briand, C., Vaslet, D., Vachard, D., Coquel, R. \& Maslo, A. 1996. Stratigraphy and sequence stratigraphy of the Moscovian in the Donets basin. Tectonophysics, 268, 189-209.

Jackson, J.W. 1927. New Carboniferous Lamellibranchs and notes on other forms. Memoirs and Proceedings of the Manchester Literary and Philosophical Society, 71, 93-122.

Kanis, J. 1956. Geology of the eastern zone of the Sierra del Brezo (Palencia - Spain). Leidse Geologische Mededelingen, 21, 377-445.

Keller, M., Bahlburg, H., Reuther, C.-D. \& Weh, A. 2006. The Pisuerga-Carrión Unit, Cantabrian Mountains (Spain): sedimentation in a broken foreland basin? Kölner Forum Geologie und Paläontologie, 15, 59-60.

Kidston, R. \& Jongmans, W.J. 1915. A Monograph of the Calamites of Western Europe. Mededeelingen Rijks Opsporing van Delfstoffen, 7, 207 p. (1917), pls 1-158 (1915).

Koopmans, B.N. 1964. Refolding in the thrust fault zone of San Martín de los Herreros (Prov. Palencia, Spain). Breviora Geológica Astúrica, VIII, 11-26.

Kullmann, J. 1962. Die Goniatiten der Namur-Stufe (Oberkarbon) im Kantabrischen Gebirge, Nordspanien. Abhandlungen der mathematisch-naturwissenschaftliche Klasse der Akademie der Wissenschaften und der Literatur in Mainz, (1962) 6, 119 pp.

Kullmann, J. 1973. Los goniatites del Devónico superior y del Carbonífero de los Pirineos Occidentales de España. Boletín Geológico y Minero de España, 84, 93-100.

Kullmann, J. 1979. Die "Reticuloceras-Zeit" (Oberkarbon) in der Entwicklung des Kantabrischen Variszikums. Clausthaler Geologische Abhandlungen, 30, 34-44.

Leuchs, K. 1919. Marines Oberkarbon im zentralen Tianschan. Sitzungsberichte der Bayerischen Akademie der Wissenschaften. Mathematisch-physikalische Klasse, 1919, 217-228.

Leyva, F., Granados, L.F., Solovieva, M.N., Reitlinger, E.A., Martínez Díaz, C., Laveine, J.P., Loboziak, S., Brousmiche, C., Candilier, A.M. \& Horvath, V. 1985. La estratigrafía del Carbonífero Medio en el sector central de la Unidad Estructural de la Sobia-Bodón (Cuencas de Quirós-Teverga). Dixième Congrès International de Stratigraphie et de Géologie du Carbonifère, Madrid, 1983, Compte Rendu, 1, 213-230.

Librovitch, L.S. 1941. Otryad Ammonoidea. In: Atlas rukovodiashchikh form iskopaemykh faun SSSR. 4: Nizhnii otdel kamennougolinoi sistemy. Gosgeolizdat, 137-153.

Librovitch, L.S. 1957. O nekotorykh novykh gruppakh goniatitov iz kamennougolinykh otlozheni SSSR. Ezhegodnik vsesoiuznogo paleontologischeskogo obshchestva, 16, 246-273.

Marín, J.A. 1997. Estructura del Domo de Valsurbio y borde suroriental de la Región del Pisuerga-Carrión (Zona Cantábrica, NO de España). Unpublished Ph.D. Thesis, Departamento de Geología, Universidad de Oviedo, 181 pp.

Marín, J.A., Villa, E., García-López, S. \& Menéndez, J.R. 1996. Estratigrafía y metamorfismo del Carbonífero de la zona de San Martín-Ventanilla (Norte de Palencia, Cordillera Cantábrica). Revista Sociedad Geológica de España, 9, 241-251.

Martínez Chacón, M.L. \& Bahamonde, J.R. in press. Brachiopods in the steep slope of a Pennsylvanian carbonate platform (Sierra del Cuera, Asturias, N. Spain). Proceedings V International Brachiopod Congress, Copenhagen, 2005.

Martínez Chacón, M.L. \& Winkler Prins, C.F. in press. Medio siglo de estudios de los Braquiópodos del yacimiento de Latores (SO Oviedo). I Congreso de Estudios Asturianos, Oviedo, 2006.

Martínez Chacón, M.L., Menéndez Álvarez, J.R., Sánchez de Posada, L.C. \& Truyols, J. 1985. Aportaciones al conocimiento de la Formación Ricacabiello (Carbonífero de la Zona Cantábrica, N. de España) y su contenido paleontológico. Trabajos de Geología, 15, 53-65.

McCaleb, J.A. 1964. Two new genera of Lower Pennsylvanian Ammonoids from Northern Arkansas. Oklahoma Geology Notes, 24 (10), 233-237.

McCaleb, J.A. 1968. Lower Pennsylvanian Ammonoids from the Bloyd Formation of Arkansas and Oklahoma. Special Paper of the Geological Society of America, 96, 123 pp.

Moore, L. R., Neves, R., Wagner, R.H. \& Wagner-Gentis, 
C.H.T. 1971. The stratigraphy of the Namurian and Westphalian rocks of the Villamanín area of northern León. Trabajos de Geología, 3 (The Carboniferous of Northwest Spain, vol. I), 307-363.

Nassichuk, W.W. 1975. Carboniferous ammonoids and stratigraphy in the Canadian Arctic Archipelago. Geological Survey of Canada, Bulletin, 237, 240 pp.

Nemyrovska, T.I. 1999. Bashkirian conodonts of the Donets Basin, Ukraine. Scripta Geologica, 119, 115 pp.

Nemyrovska, T.I. 2005. Late Viséan/early Serpukhovian conodont succession from the Triollo section, Palencia (Cantabrian Mountains, Spain), with an appendix by Elias Samankassou. Scripta Geologica, 129, 13-89.

Nemyrovska, T.I. \& Alekseev, A.S. 1995. The Bashkirian conodonts of the Askyn section, Bashkirian Mountains, Russia. Bulletin de la Société belge de Géologie, 103 (1-2: Volume en hommage à Raphaël Conil), 109-133.

Plummer, F.B. \& Scott, G. 1937. Upper Paleozoic ammonites in Texas. Bulletin Texas University, 3071, 516 pp.

Rauser-Chernousova, D.M. 1928. O nekotorykh kamennougol'nykh ammonitakh Fergany. Izvestiia Assotsiatsii Nauchno-issledovatalskikh Institutov pri Fizikomatematicheskomu Fakultete, Universitet Moskva, 1, 164-178. (mit Deutscher Zusammenfassung: Über die Carbonammonitenfauna von Fergana.)

Rodríguez Fernández, L.R. 1994. La estratigrafía del Paleozoico y la estructura de la región de Fuentes Carrionas y áreas adyacentes (Cordillera Herciniana - N.O. de España). Laboratorio Xeoloxico de Laxe, Nova Terra, 9, $240 \mathrm{pp}$.

Rodríguez Fernández, L.R., Heredia, N., Lobato, L. \& Velando, F. 1985. Camporredondo de Alba. Instituto Geológico y Minero de España, Mapa Geológico de España, Escala 1:50.000, 106 (16-7), 98 pp.

Ruan, Y. 1981. Carboniferous ammonoid faunas from Qixu in Nandan of Guangxi. Memoirs Nanjing Institute of Geology and Palaeontology, Academia Sinica, 15, 153-232.

Ruzhentsev, V.-E. 1957. Filogenicheskaya sistema paleozoiskikh ammonoidei. Biulletin Moskovskogo obshchestva isputatelei prirody, otdelenie geologii, 32, 49-64.

Ruzhentsev, V.E. \& Bogoslovskaya, M.F. 1969. Reviziya semejstva Dimorphoceratidae. Paleontologicheskogo Zhurnal, 1969, 51-66 (translation: Revision of the family Dimorphoceratidae, Paleontological Journal, 3, 43-56).

Ruzhentsev, V.E. \& Bogoslovskaya, M.F. 1971. Namiurskii etap v evoliutsii ammonoidei. Rannenamiurskie ammonoidei. Trudy Paleontologicheskogo Instituta, Akademia Nauk SSSR, 133, 1-382.

Ruzhentsev, V.E. \& Bogoslovskaya, M.F. 1975. O semeistve Reticuloceratidae i smezhnykh taksonakh. Paleontologicheskii Zhurnal, 1975, 46-61.

Ruzhentsev, V.E. \& Bogoslovskaya, M.F. 1978. Namiurskii etap v evoliutsii ammonoidei. Pozdnenamiurskie ammonoidei. Trudy Paleontologicheskogo Instituta, Akademia Nauk SSSR, 167, 1-338.

Savage, J.F. \& Boschma, D. 1980. Geological maps of the southern Cantabrian Mountains (Spain). Leidse Geologische Mededelingen, 50, 75-114.
Schindewolf, O.H. 1939. Zur Kenntnis von Pericleites RENZ und verwandter paläozoischer Ammoneen. Jahrbuch der Preußischen Geologischen Landesanstalt für 1938, 59, 423-455.

Schindewolf, O.H. \& Kullmann, J. 1958. Goniatites devónicos y carboníferos de la Cordillera Cantábrica. Estudios Geológicos, 14, 45-53.

Schmidt, H. 1929. Tierische Leitfossilien des Karbon. In: Gürich. Leitfossilien, 6, 107 pp.

Schmidt, H. 1955. Einige Goniatiten aus spanischem Oberkarbon. Publication Association Études Paléontologie Stratigraphie houillères (volume hommage F. Demanet), 21 (Hors Série), 47-59.

Stepanov, D.L. and others 1962. The Carboniferous System and its main stratigraphic subdivisions. Report of the Commission on the Stratigraphy of the Carboniferous of the National Committee of Soviet Geologists. $4^{e}$ Congrès pour l'avancement des études de Stratigraphie et de Géologie du Carbonifère, Heerlen, 1958, Compte Rendu, 3, 645-656.

Sternberg, K. von 1820-1838. Versuch einer geognostischbotanischer Darstellung der Flora der Vorwelt. I (18201825) 1 (1820): 1-24, Tafn I-XIII; 2 (1823): 1-33, Tafn XIV-XXVI; 3 (1824): 1-40, Tafn XXVII-XXXIX; 4 (1825): 1-48, Tafn XL-LIX, Tafn A-E. II (1833-1838) - 5/6 (1833): 1-80, Tafn I-XXVI; 7/8 (1838, Presl): 81-220, Tafn I-LXVIII, Tafn A, B (incl. Corda: Skizzen zur vergleichenden Phytotomie vor- und jetztweltlicher Pflanzenstämme, I-LXXI).

Stockmans, F. \& Willière, Y. 1965. Documents paléobotaniques pour l'étude du Houiller dans le Nord-Ouest de l'Espagne. Institut Royal des Sciences naturelles, Mémoires, (2), 79, pls I-XXXVIII. Published April 1966.

Vachard, D. \& Maslo, A. 1996. Précisions biostratigraphiques et micropaléontologiques sur le Bashkirien d'Ukraine (Carbonifère moyen). Revue de Paléobiologie, 15, 357383.

Villa, E. 1982. Observaciones sobre la edad de la Formación Valdeteja (Carbonífero, NW de España) en su área-tipo. Revista Española de Micropaleontología, 14, 63-72.

Villa, E. 1989. Foraminíferos bashkirienses de la Sierra del Sueve (Cuenca Carbonífera Central, Zona Cantábrica, NW de España). Revista Española de Paleontología, 4, 81-89.

Villa, E., Horvath, V., Martínez-Chacón, M.L. \& Sánchez de Posada, L.C. 1988. Datos paleontológicos y edad de la sección de Villamanín (Carbonífero, C. Cantábrica, NW de España). II Congreso Geológico de España, Comunicaciones, 1, 337-341.

Villa, E., Bahamonde, J.R., Martínez-Chacón, M.L., Martínez García, E., Méndez, C.A., Rodríguez, R.M. \& Sánchez de Posada, L.C. 2000. The Carboniferous of eastern Asturian (Cantabrian Zone, northern Spain). Guidebook of Fieldtrip of the Working Group to establish a GSSP in the upper part of the Carboniferous System (SCCS Project 5).

Villa, E., Sánchez de Posada, L.C., Fernández, L.P., Martínez-Chacón, M.L. \& Stavros, Ch. 2001. Foraminifera and Biostratigraphy of the Valdeteja Formation Stratotype 
(Carboniferous, Cantabrian Zone, NW Spain). Facies, 45, 59-86.

Wagner, R.H. 1959. Flora fósil y estratigrafía del Carbonífero de España NW. y Portugal N. Estudios Geológicos, XV, 393-420.

Wagner, R.H. 1962. A brief review of the stratigraphy and floral succession of the Carboniferous in NW. Spain. $4^{e}$ Congrès pour l'Avancement des Études de Stratigraphie et de Géologie du Carbonifère, Compte Rendu, III, 753762.

Wagner, R.H. 1971. Carboniferous nappe structures in northeastern Palencia (Spain). Trabajos de Geología, 4 (The Carboniferous of Northwest Spain, vol. II), 431-459, pls 1-7.

Wagner, R.H. \& Álvarez-Vázquez, C. 1995. Upper Namurian/lower Westphalian of La Camocha, Asturias: Review of floral and faunal data. Coloquios de Paleontología, 47 (volumen en homenaje al profesor Bermudo Meléndez, II), 151-176.

Wagner, R.H. \& Bowman, M.B.J. 1983. The position of the Bashkirian/Moscovian boundary in West European chronostratigraphy. Newsletters on Stratigraphy, 12, 132-161.

Wagner, R.H. \& Wagner-Gentis, C.H.T. 1963. Summary of the stratigraphy of Upper Palaeozoic rocks in NE. Palencia, Spain. Proceedings Koninklijke Nederlandse Akademie van Wetenschappen, B, 66, 149-163.

Wagner, R.H. \& Winkler Prins, C.F. 1997. Discusión. Estratigrafía y metamorfismo del Carbonífero de la zona de San
Martín-Ventanilla (Norte de Palencia, Cordillera Cantábrica): Comentarios críticos. Revista Sociedad Geológica de España, 10, 197-199.

Wagner, R.H. \& Winkler Prins, C.F. 2000. Carboniferous stratigraphy of the Sierra del Brezo in northern Palencia: evidence of major uplifts. Trabajos de Geología, 21, 385-403.

Wagner, R.H. \& Winkler Prins, C.F. in prep. Stratigraphy and structure of the Upper Devonian, Mississippian and lower Pennsylvanian North of the Carrionas/Ruesga Fault, northern Palencia. Scripta Geologica.

Wagner, R.H., Carballeira, J., Ambrose, T. \& Martínez García, E. 1984. Barruelo de Santullán. Instituto Geológico y Minero de España, Mapa Geológico de España, Escala 1:50.000, 107 (17-7), 1-113.

Wagner-Gentis, C.H.T. 1985. A possible Atokan goniatite fauna from basal Moscovian (Westphalian A) deposits at Piedrasluengas, N.W. Spain. Senckenbergiana lethaea, 65, 337-345.

Winkler Prins, C.F. in press. The role of Spain in the development of the reef brachiopod faunas during the Carboniferous. In: Biogeography, Time and Place: Distribution, Barriers and Islands (ed. W. Renema). Kluwer/Springer, Dordrecht.

Manuscrito recibido: 15 de Septiembre, 2006 Manuscrito aceptado: 25 de Junio, 2007 